\title{
A agenda do professor-pesquisador em Administração: uma análise baseada na sociologia da ciência ${ }^{1}$
}

\author{
The agenda of the professor-researcher in Administration: an analysis based on sociology \\ of scientific knowledge
}

Danilo Melo $^{2}$
Maurício Serva $^{3}$

\section{Resumo}

A Administração é considerada uma ciência nova, caso seja comparada às ciências tradicionais. O Ensino Superior em Administração no Brasil teve início na década de 1950, importando metodologias americanas de ensino. A partir da formação de professores e pesquisadores, a pesquisa científica nacional em Administração passa a ser desenvolvida e a ser parte essencial para a formulação de teorias e metodologias adequadas à realidade brasileira. Nesse contexto, a sociologia da ciência surge como perspectiva essencial para a compreensão do saber científico, colocando no centro da investigação o pesquisador, ator do campo científico, bem como suas relações dentro do campo. Com o objetivo de aprofundar a compreensão sobre o conteúdo do trabalho do professor-pesquisador em Administração, tendo em vista a necessidade dos integrantes desse campo de compreendê-lo melhor e de maneira sistematizada, este artigo visa a responder a seguinte questão: "Qual é o conteúdo do trabalho do professor-pesquisador, quais são seus objetivos e as atividades que compõem sua agenda?". Por meio deste estudo, predominantemente qualitativo, aprofundou-se o conhecimento sobre as atividades com as quais os professores-pesquisadores em Administração estão envolvidos e seus objetivos quando entraram no campo e seus objetivos atuais, assim como se estruturou a agenda do professorpesquisador com base na agenda dos entrevistados. Percebeu-se que a carga de trabalho desse profissional excede as 50 horas semanais e que as atividades de pesquisa, as predominantes em relação ao objetivo atual desses profissionais, são desprivilegiadas na semana, sendo deixadas para o final de semana em $47 \%$ dos casos.

Palavras-chave: Ciência da administração. Sociologia da ciência. Campo científico da administração. Brasil.

\section{Abstract}

Administration is regarded as a new science, if compared to the traditional sciences. Higher Education in Administration in Brazil began in the 1950s, by importing American teaching methodologies. In this context, sociology of scientific knowledge emerges as a crucial perspective to understand scientific knowledge, putting the researcher in the eye of investigation, since she/he is the actor in the scientific field, as well as her/his relationships within the field. In order to

Artigo submetido em 03 de maio de 2013 e aceito em 04 de abril de 2014.

DOI: http://dx.doi.org/10.1590/1679-39518559

${ }^{1}$ Este artigo é fruto de uma pesquisa apoiada pelo Conselho Nacional de Desenvolvimento Científico e Tecnológico - CNPq.

2 Mestre em Administração pela Universidade Federal de Santa Catarina; Membro do Núcleo Organizações, Racionalidade e Desenvolvimento (www.redeord.com). Endereço: UFSC, Campus Trindade, Centro Socioeconômico, sala 229, CEP 88040-900, Florianópolis - SC, Brasil. E-mail: danilomelo@live.com

3 Doutor em Administração pela EAESP/FGV; Professor da Universidade Federal de Santa Catarina; Coordenador do Núcleo Organizações, Racionalidade e Desenvolvimento (www.redeord.com); Editor da revista Ciências em Debate. Endereço: UFSC, Campus Trindade, Centro Socioeconômico, sala 229, CEP 88040-900, Florianópolis - SC, Brasil. E-mail: mauserva@gmail.com 
deepen understanding on the content of the work of the professor-researcher in Administration, having in mind the need of individuals within this field to understand it better and in a systematized way, this article aims to answer to the following question: "What is the content of the professor-researcher's work, which are her/his goals and the activities that make up her/his agenda?". Through this study, predominantly qualitative, we deepened knowledge on the activities in which professors-researchers in Administration are involved and their objectives when entering the field and their current objectives, and we also structured the professor-researcher's agenda having respondents' agenda as a basis. We found out that the workload of this professional is over 50 hours a week and that research activities, which prevail with regard to the current objective of these professionals, are underprivileged on weekdays, being left for the weekend in $47 \%$ of cases.

Keywords: Administration science. Sociology of scientific knowledge. Scientific field of administration. Brazil.

\section{Introdução}

A Administração como ciência, se comparada às principais ciências sociais e naturais, é considerada uma ciência recente. Foi somente no início do século XX que a Administração começou a se estabelecer como ciência, por meio dos estudos de Frederick Taylor, fundando o que se denominou Administração Científica. A Administração como disciplina científica e como profissão institucionalizada constituem realidades históricas pertencentes ao século passado e o Ensino Superior em Administração possui história relativamente recente, difundindo-se nos últimos cem anos (MATOS, BALBACHEVSKY, SAMPAIO et al., 2002). Já no Brasil, a institucionalização da Administração é ainda mais recente, pois as primeiras escolas de Ensino Superior foram instituídas na década de 1950, visando a suprir a necessidade da política desenvolvimentista de pessoal qualificado para gerir órgãos públicos e empreendimentos privados. Nesse processo de implantação, o Brasil contou com o apoio de escolas americanas tradicionais (Michigan University, University of Southern California) para a capacitação dos professores, assim como para a transferência dos currículos dos cursos, das metodologias de ensino e dos acervos das primeiras bibliotecas (SERVA, 1992).

Nas últimas décadas do século passado, houve uma grande expansão do ensino da Administração no Brasil. Em 2011, segundo o censo do Instituto Nacional de Estudos e Pesquisa (INEP) e do Ministério da Educação (MEC) publicado em 2013, a área de Gerenciamento e Administração liderava o número de matrículas no país, somando 1.279.297 alunos, distribuídos em mais de 1.600 instituições de ensino. Portanto, a Administração se tornou o maior curso de graduação do Brasil. Esses números mostram a representatividade da área para o país e, em consequência, a amplitude da atuação do professor de Administração perante a sociedade, considerando a questão da formação.

Na pós-graduação - nível de interesse deste artigo -, contudo, observa-se que a produção científica em Administração se expande e intensifica efetivamente a partir dos anos 1980. Como veremos, duas instituições foram decisivas nesse processo: a Coordenação de Aperfeiçoamento de Pessoal de Nível Superior (Capes) e a Associação Nacional de Pós-Graduação e Pesquisa em Administração (Anpad). Em 2014, a Anpad já conta com quase uma centena de programas de pós-graduação em Administração, todos oficializados pela Capes. Por conseguinte, constata-se a existência de um efetivo campo científico com densidade significativa. A carreira de professor de Administração em cursos superiores passa, então, a ser buscada por centenas de profissionais em todo o país. Uma das características mais marcantes dessa carreira é sua elevada diversidade interna, considerando a inserção do profissional de acordo com o nível de atuação (graduação, pós-graduação lato sensu, pós-graduação stricto sensu), a instituição em que atua (pública, privada), o regime específico de trabalho (tempo integral, tempo parcial), as atividades que desempenha, dentre outros aspectos. Malgrado a magnitude do campo de trabalho desse profissional, bem como a quantidade dos cursos de formação, há poucos estudos científicos sobre esse campo que podem integrar o conteúdo pedagógico da formação desses profissionais.

Neste estudo, discutimos especificamente questões ligadas ao professor de Administração que atua tanto no nível de graduação como no nível de pós-graduação stricto sensu e que, por conseguinte, tem seu trabalho 
regulado pelas normas específicas de avaliação da produção científica instituídas no Brasil. Esse profissional é designado, aqui, "professor-pesquisador". Interessa-nos analisar o conteúdo do trabalho desse professor, situando-o em um plano mais amplo, em uma perspectiva eminentemente sociológica, ao considerar que as atividades que ele desempenha estão inscritas socialmente em um campo profissional que tem regras, modalidades e espaços semiautônomos em relação a outros campos profissionais. Ao discutir cientificamente o conteúdo do trabalho e as condições que o cercam, objetiva-se oferecer uma contribuição à formação dos futuros profissionais, proporcionando aos programas de pós-graduação em Administração no Brasil a possibilidade de inserir essa discussão no rol dos conhecimentos abordados. Considera-se que a ausência dessa discussão em bases científicas constitui uma lacuna no processo pedagógico - formamos profissionais da ciência, mas não discutimos de modo científico seu campo -, assim, almeja-se com este artigo contribuir para a redução dessa lacuna. Além disso, também se almeja que este estudo tenha um caráter "reflexivo", em conformidade com as ideias de Bourdieu (1994), de Berry (1995) e de outros autores a respeito da contribuição que a sociologia da ciência pode dar à autocrítica dos profissionais das ciências.

A sociologia da ciência, ao conceber que a "verdade" do produto científico reside em uma espécie particular de condições sociais de produção no campo de determinada ciência, revela a necessidade de empreender análises rigorosas do campo em si (BOURDIEU, 1994). Baseando-se em Pierre Bourdieu, Michel Audet (1986) discute o conceito de campo e também o interesse em empregar esse conceito para tratar do desenvolvimento e do conteúdo da ciência administrativa. Audet (1986) identifica os três grupos de atoreschave no campo da produção científica em Administração: i) os professores e pesquisadores universitários; ii) os consultores organizacionais; e iii) os gestores profissionais. $\mathrm{O}$ autor considera os primeiros produtores de conhecimento e os últimos práticos. Ainda que tal identificação possa ser considerada limitada (menos diversificada) em relação ao caso brasileiro na atualidade - Audet (1986) analisava a realidade canadense, mais especificamente a situação do campo no Quebec -, pode-se tomar essa classificação dos atores-chave como ponto de partida. Segundo alguns autores da sociologia da ciência, os pesquisadores enquanto intelectuais contemporâneos são produtos das universidades (LECLERC, 2005); eles conduzem seu trabalho de maneira relativamente independente (DORTIER, 2001). No caso dos professores-pesquisadores em Administração, constatam-se as pressões que exercem influência sobre seu trabalho, de um lado pela influência inerente a um campo que tem forte interação com o mercado, por outro lado, as pressões por publicação oriundas dos sistemas de avaliação. Assim, ser professor-pesquisador é participar de colóquios, é publicar e, também, lecionar. Em tese, isso significa passar muito tempo na organização de material de pesquisa. Na função de pesquisadores, os atores precisam, ainda, obter financiamento, preparar entrevistas e viagens, fazer contato com os colegas e os informantes de suas pesquisas. Além disso, na função de professores, participam fortemente das funções de ensino e participam de atividades burocráticas. A pesquisa de Michel Berry (1995) realizada em um centro de pesquisa em gestão em Paris, o Centre de Recherche en Gestion (CRG) da prestigiosa École Polythecnique apresenta um desacordo entre o que o pesquisador deveria e o que ele pode fazer, mostrando a necessidade de 9 a 12 dias para a semana ideal de um pesquisador. O professor-pesquisador, categoria que envolve as duas funções, portanto, desempenha uma série de atividades diferentes no seu dia a dia, porém não se tem um conhecimento científico aprofundado sobre o conteúdo do trabalho desse ator no campo científico da Administração no Brasil; tampouco sobre a maneira como ele organiza sua agenda em função da quantidade de atividades que lhe são atribuídas.

Sob a perspectiva do trabalho elaborada por Pierre Bourdieu, o objetivo dos atores nesse campo é a acumulação de um tipo específico de capital simbólico: o capital científico. Sob essa perspectiva, o trabalho dos pesquisadores sofre influência das condições de produção e, dessa maneira, entender essas condições é entender o fruto de seu trabalho. Por essa razão, o estudo do campo científico é intrigante e motivador, já que o pesquisador se defronta com ele mesmo, com seus pares e com seu campo de trabalho, questionando sua produção e a si próprio (SERVA e PINHEIRO, 2009), daí decorre o caráter reflexivo deste estudo.

Tendo em vista a falta de pesquisas que aprofundem o conhecimento sobre o campo de atuação do professorpesquisador em Administração no Brasil, com o foco nesse ator produtor de conhecimento, surge a questão de pesquisa que norteia este artigo: "Qual é o conteúdo do trabalho do professor-pesquisador, quais são seus objetivos e as atividades que compõem sua agenda?". 
Visando a responder essa questão de pesquisa, são apresentadas notas sobre a sociologia da ciência. Posteriormente, são apresentados os procedimentos metodológicos empregados na pesquisa, seguidos da análise e das considerações finais.

\section{Notas sobre a Sociologia da Ciência}

Um dos temas de pesquisa mais férteis dessa especialidade sociológica é o estudo do campo científico: "A análise do campo é, portanto, uma possibilidade de avanço da ciência a partir da compreensão daqueles que a produzem" (SERVA e PINHEIRO, 2009, p. 1). Para Bourdieu (1994), os conflitos epistemológicos serão sempre conflitos políticos.

O ponto de partida da investigação sociológica sobre a ciência se situa nos anos 1940, com os trabalhos de Robert Merton. Em um artigo publicado originalmente em 1942, intitulado "The normative structure of science", o autor visualiza a ciência, ou seja, as instituições científicas e seus membros, como um espaço regido por um sistema de quatro normas: o universalismo; o caráter coletivo da ciência; o desinteresse (os cientistas não são movidos por interesses privados); e o ceticismo organizado (os resultados experimentais devem ser submetidos à critica coletiva) (MERTON, 1973). Entretanto, nos anos 1970, Pierre Bourdieu promoveu uma inflexão nessa disciplina, inaugurando uma vertente crítica. Diante da necessidade de escapar à alternativa da "ciência pura" - completamente livre de necessidade social -, e da "ciência escrava" dominada por todas as demandas político-econômicas -, Bourdieu (2004a) considera importante analisar a estrutura das relações objetivas entre os agentes, o que denomina "princípios do campo".

A partir da contribuição de Pierre Bourdieu, a sociologia da ciência se esforça para responder questões a respeito: do modo de funcionamento e de organização do espaço científico; da natureza do trabalho realizado pelos cientistas, enquanto agentes integrantes de uma profissão; de como funciona a comunidade científica; de como se dão as relações entre os profissionais da ciência; do que comanda as intervenções científicas, os lugares de publicação, os temas escolhidos, os objetos que interessam; da influência do contexto sobre o conhecimento produzido (BOURDIEU, 1994; 2004a). Segundo Fetz, Defacci e Nascimento (2011, p. 285),

[...] em linhas gerais, a sociologia da ciência é uma tentativa fecunda de abarcar a ciência não mais de maneira isolada, mas em sua necessária relação com os eventos externos que a circunscreve e que, em grande medida, condiciona as suas descobertas.

Dessa forma, é fundamental entender o campo científico e ampliar a compreensão dos seus elementos, pois é nele que ocorre a produção do conhecimento.

Na seção seguinte, será apresentado, sob a perspectiva dos trabalhos do sociólogo francês Pierre Bourdieu, o conceito de campo científico, um dos mais importantes da sociologia da ciência de cunho crítico. Esclarecemos que dentre os diversos conceitos elaborados por Pierre Bourdieu em sua extensa obra, empregaremos apenas os conceitos de campo científico e de capital científico, haja vista a contribuição desse conceito para a sociologia da ciência e, em particular, para a discussão desenvolvida neste artigo. Ademais, a análise dos dados levantados empiricamente no campo não se circunscreve somente na teoria de Pierre Bourdieu, na medida em que nos baseamos também em outros autores da sociologia da ciência.

\section{O campo científico}

Concebido como um espaço de conflitos, o campo científico é um "sistema de relações objetivas entre posições adquiridas em lutas anteriores - é o lugar e o espaço de uma luta concorrencial" (BOURDIEU, 1994, p. 122). Para Bourdieu (1976, p. 112), o campo científico é um campo social como outro qualquer, "com suas relações de força e monopólios, lutas e estratégias, interesses e lucros, no qual todas essas 
invariantes assumem formas específicas". O autor defende que é inútil distinguir entre as determinações científicas, puras e as determinações sociais, ou seja, o interesse científico do interesse pela autoridade científica - o prestígio, o reconhecimento, a celebridade. Assim, um campo é, ao mesmo tempo, um lugar e um sistema. Ao aceitar tal concepção, estaríamos, também, segundo Bourdieu (2004b, p. 54), valorizando a formulação e a busca de respostas para determinadas questões:

A teoria do campo orienta e comanda a investigação empírica. Obriga a formular a questão de saber o que é que se joga nesse campo, o que está em jogo, quais os bens ou as propriedades procuradas e distribuídas ou redistribuídas, e como é que se distribuem, quais são os instrumentos ou as armas que se deve ter para jogar com hipóteses de ganhar e qual é, em cada momento do jogo, a estrutura da distribuição dos bens, ganhos e trunfos, ou seja, do capital específico.

Bourdieu (1976, p. 112) aprofunda a discussão do que está em jogo, afirmando que o que está em luta são os monopólios da autoridade e competência científicas que são socialmente concedidas a determinado agente. $\mathrm{Na}$ autoridade avalia-se capacidade técnica e poder social, já na competência científica a capacidade de falar e agir legitimamente. Assim, as relações de força científicas são relações de conhecimento e comunicação (BOURDIEU, 2004b), e a diferença entre um campo e um jogo qualquer é que no campo as regras estão elas próprias em jogo (BOURDIEU, 2004a), ou seja, o jogo se estende à luta pela definição das regras. O autor acrescenta que as estratégias no campo científico sempre apresentam duas facetas: i) função puramente científica; ii) "função social no campo, ou seja, em relação aos outros agentes envolvidos no campo" (BOURDIEU, 2004b, p. 79). Dessa maneira, uma análise que tratasse de modo separado a dimensão puramente científica e os conflitos pela dominação no campo científico seria falsa. Bourdieu (2004a) acrescenta que na compreensão desse espaço socioprofissional um laboratório também deve ser considerado um campo ou mesmo um subcampo, já que dispõe de autonomia relativa às limitações associadas à sua posição na estrutura do campo disciplinar e, enquanto espaço de um jogo específico, contribui para determinar as estratégias dos agentes. Há, ainda, que se avaliar as instituições científicas cujo funcionamento, composição social e estrutura organizacional devem ser compreendidas em função da lógica de campo, incluindo as formas organizacionais que estruturam a prática dos agentes e suas interações, citando no caso francês o Centre National de la Recherche Scientifique (CNRS) - instituição de fomento que apresenta alguma semelhança com a instituição brasileira Conselho Nacional de Desenvolvimento Científico e Tecnológico (CNPq).

No campo científico, acumular capital significa "fazer um 'nome', um nome próprio, um nome conhecido e reconhecido, marca que distingue imediatamente seu portador [...]" (BOURDIEU, 1994, p. 132). Esse campo apresenta um fenômeno que é destacado pelo autor: o reconhecimento do valor dos produtos provém dos seus pares, os quais são, ao mesmo tempo, concorrentes pela definição de ciência; por conseguinte, os pares são menos inclinados a reconhecer o valor dos produtos sem discussão ou exame. O que é percebido como importante e interessante é o que tem chances de ser reconhecido como tal pelos outros, seus pares (BOURDIEU, 2004a). Para obter esse reconhecimento pelos seus pares concorrentes, é necessário que a obra tenha um valor distintivo e seja original na contribuição que traz aos recursos científicos já acumulados (BOURDIEU, 1994). Dortier (2001) defende que as relações com os colegas constituem um aspecto interessante do campo, sempre ambíguas, já que há o interesse em dividir resultados, sendo os pares os principais avaliadores e aqueles que poderão contribuir com o trabalho. Entretanto, ao mesmo tempo, há a competição, concorrência pela busca dos resultados, por exemplo. Os produtores têm "como clientes apenas os seus adversários mais rigorosos, os mais competentes e críticos” (BOURDIEU, 2004b, p. 78).

No caso do Ensino Superior francês, analisado detalhadamente por Bourdieu (1984), a distribuição de professores é tal que quanto mais próximos do polo de poder, menos prestígio se tem, em termos de indicadores de produção científica. Nesse processo, então, as duas estruturas estão dispostas de maneira inversamente proporcional (BOURDIEU, 2004a, p. 42): 
[...] de um lado, as pessoas mais poderosas, em particular do ponto de vista do controle da reprodução do corpo (aqueles que têm assento no CNU, nas grandes comissões examinadoras de concursos etc.) e da perpetuação do paradigma, da ortodoxia; de outro, as pessoas que têm o prestígio, a notoriedade, o reconhecimento, sobretudo internacional, mas que têm pouco poder. Essa discordância é geradora de todo um conjunto de efeitos.

Entre esses efeitos, tal configuração permite aos que fracassam no campo científico imputar sua má posição intelectual à sua má posição na economia do poder (BOURDIEU, 2004a). Outro problema, destacado pelo autor, está relacionado tanto às disciplinas que demandam uma maior quantidade de recursos para se desenvolver quanto a certos pesquisadores que se tornaram administradores científicos, os quais, por intermédio do controle de recursos, exercem um poder demasiado no campo. Bourdieu (2004a) percebe, ainda, que um dos grandes paradoxos dos campos científicos é que devem, em ampla medida, sua autonomia ao fato de que são subsidiados pelo Estado e, portanto, sustenta-se uma produção que não está submetida à sanção imediata do mercado, mas que, em alguns setores, o Estado pode interferir de acordo com seus interesses e impor constrangimentos por meio de pressões de força econômica. Ainda em relação ao campo e às forças externas, Bourdieu (2004a, p. 22) considera que "uma das manifestações mais visíveis da autonomia do campo é sua capacidade de refratar, (re)traduzindo sob uma forma específica as pressões ou as demandas externas". Além disso, a atividade científica implica determinado custo econômico e o grau de autonomia de uma ciência depende do grau de necessidade que ela demanda para se concretizar. Entretanto, determinado campo depende, sobretudo, do grau como está protegido contra intrusões capazes de impor sanções positivas ou negativas.

Uma vez que este estudo põe em destaque os atores do campo, a próxima seção apresenta resumidamente alguns estudos sobre pesquisadores realizados com base na sociologia da ciência.

\section{$\mathrm{O}$ pesquisador}

Segundo Berry (1995), o pesquisador é um homem apressado, já que sua carga de trabalho ultrapassa o tempo que esse profissional pode dedicar a ela. Há um desacordo entre as tarefas que deveria fazer e aquilo que efetivamente pode fazer, sendo muitas vezes obrigado a criar medidas para adiar as atividades mais difíceis, como o desenvolvimento de novas ideias. Como visto na introdução, o trabalho de Berry (1995) ilustra esse desacordo entre o que deveria e o que pode fazer, estimando o tempo médio de trabalho de um pesquisador em gestão do CRG; seu estudo inspirou esta pesquisa. O estudo realizado por Berry (1995) demonstrou a necessidade de trabalho de 9 a 12 dias na semana de um pesquisador ideal, considerando a descrição do emprego de seu tempo nas diferentes etapas de sua carreira. E, como afirma o autor, os pesquisadores do CRG não são os únicos a ter problemas dessa ordem, inclusive, lembra que alguns pesquisadores chegam a dispensar o ensino. É necessário, então, renunciar ou destinar menos tempo a algumas das seguintes atividades: ler, escrever, trabalhar coletivamente, ensinar, administrar ou, no âmbito externo ao trabalho, relacionar-se com sua família. Destaca-se que cada pesquisador, em função de seu tempo de carreira, aptidões e envolvimento com o campo científico, faz uma escolha específica de renúncia a alguma atividade. Algumas atividades, ainda, são mais difíceis de ser renunciadas, como as entrevistas, as reuniões formais, e, se houver pressão acadêmica por produção científica, o pesquisador deverá adotar estratégias diferentes dos profissionais que possuem uma carga de ensino pesada.

Michel Berry (1995) também apresenta, com base na lógica de arbitragens cotidianas de empresas elaboradas por Delpeuch e Lauvergeon (1986), três esferas distintas nas atividades de um pesquisador do CRG: i) a esfera das obrigações, aí compreendidas as aulas em horários fixos e reuniões das instituições de que faz parte - tais obrigações se acumulam à medida que o pesquisador progride na carreira; ii) a esfera das solicitações, isto é, encontros de campo, propostas de colaboração ou de intervenção, demandas internas e externas (bancas, avaliação de trabalhos, comissões de avaliação de trabalhos); e iii) a esfera criativa, ou seja, participação em seminários ou colóquios, discussão, elaboração de trabalhos e pesquisas. Para que as atividades da esfera criativa não sejam prejudicadas, Berry (1995) ressalta que o pesquisador marca datas e 
desenvolve rituais próprios para incluir a criatividade na agenda. São as datas da agenda que concentram a mente e determinam as prioridades, as quais devem ser concluídas em tempo.

Dortier (2001) enquadra o pesquisador entre os trabalhadores intelectuais, trabalhadores do saber, e afirma que, mesmo sendo assalariado, o trabalhador gerencia seu trabalho de maneira relativamente independente. $\mathrm{O}$ autor destaca uma das características determinantes desse tipo de trabalho: sendo essencialmente de natureza intelectual, o trabalho não o deixa ao sair do escritório, está sempre ligado à internet, ao telefone e às revistas e publicações referentes às suas atividades.

Leclerc (2005) aponta que os intelectuais contemporâneos são um "produto" da universidade e, após enumerar uma série de atividades e lugares que o intelectual contemporâneo frequenta, constata que tal profissional isolado não existe. Ele pertence conscientemente a uma coletividade de pares, na qual são importantes a comunicação entre colegas, a notoriedade e a visibilidade. Além dos títulos, Leclerc (2005) elenca quatro dimensões de prestígio aos universitários: a) prestígio da instituição; b) produzir uma obra reconhecida e ter periodicidade de produção, sobretudo em artigos científicos próprios para aumentar sua reputação como pesquisador; c) editar e avaliar, controlar e gerir a produção dos pares; d) dirigir um laboratório. Portanto, o prestígio dos pesquisadores não se julga simplesmente pelo seu título, mas, para Leclerc (2005), existem pelo menos essas quatro dimensões adicionais.

Em se tratando das atividades no campo científico, o trabalho de pesquisa não se reduz a experimentar, comparar e simular para testar hipóteses. Para Dortier (2001), a vida de pesquisador não se resume ao trabalho de laboratório ou de "campo", como se diz nas ciências sociais. Ser pesquisador é participar de colóquios e, também, publicar e ensinar. O pesquisador gasta muito tempo na organização de material da pesquisa. A publicação também é, como os colóquios e os seminários, um meio de ver o reconhecimento de pesquisas e seus resultados. Entra aqui o famoso dilema do pesquisador: publish or perish.

Em uma pesquisa realizada junto a coordenadores de grupos de pesquisa de escolas de Administração no Sul do Brasil, Bini, Serva e Melo (2013) identificam as atividades de gestão requeridas a um coordenador, dentre as quais podemos citar as mais importantes, segundo os autores: articulação dos membros de modo que caminhem juntos e formem um grupo com identidade, com base teórica e objetivos comuns; gestão de conflitos; representação externa do núcleo; controle da produção científica dos membros; obtenção de recursos; controle financeiro e prestação de contas. Os autores concluem que:

O trabalho dos coordenadores de pesquisa é desafiante e trabalhoso (nas palavras dos coordenadores entrevistados) e que, diante das variáveis com que o coordenador precisa atuar, como pessoas, captação de recursos, produção científica, integração do grupo e representação do mesmo, a coordenação de um grupo de pesquisa muitas vezes exige um esforço do coordenador comparável ao de um executivo (BINI, SERVA e MELO, 2013, p. 34).

Louvel (2005) destaca cinco dimensões do mundo dos pesquisadores que podem auxiliar a ilustrar seu trabalho e sua legitimação: i) mobilizar o mundo; ii) criar colegas; iii) aliar-se a autores que se interessem pelas duas operações precedentes (a escola, o Estado, a indústria.); iv) evidenciar a atividade científica pelas relações públicas, pela confiança, pela ideologia; e v) o quinto horizonte designa o conteúdo da atividade científica, ele só existe graças aos quatro primeiros - a força das ideias e dos conceitos científicos que leva à transformação dos outros horizontes.

Reforçando o que foi mencionado, Charle (1998) ressalta o aspecto do interesse e das relações de poder que dificultam a difusão dos conhecimentos. Para o autor, à medida que os lugares de formação, de transmissão e difusão de ideias se institucionalizam, a concorrência entre grupos de intelectuais transforma-se em uma luta pelo poder e pela legitimidade. 
Como vimos, Audet (1986) identifica os grupos de atores-chave no campo da produção científica em Administração: os professores e pesquisadores universitários, os consultores organizacionais e os gestores profissionais. Estes últimos também são considerados por Audet (1986) produtores de conhecimento; a relação conhecimento/ação que os caracteriza é a de um movimento circular desencadeado por ações concretas e que desemboca em outras ações concretas após o conhecimento do objeto.

Louvel (2005) questiona o por quê da escolha da profissão, tendo em vista que a remuneração na produção de conhecimentos geralmente é inferior à de outras carreiras com nível de escolaridade e competências semelhantes. No entanto, o autor afirma que a retribuição simbólica, atribuída pelos pares, explica o motor da profissão e compensa as outras questões.

Wood Júnior (2005) trata do sentido do trabalho do cientista no campo da Administração no Brasil, utilizando a argumentação da professora Estelle Morin, da École des Hautes Études Commerciales (HEC) de Montreal, Quebec, Canadá. São analisados seis aspectos sobre o trabalho: i) é intrinsecamente satisfatório desenvolve competências, traz atualização e realização, envolve criatividade e autonomia - e, para o autor, os pesquisadores da área são privilegiados; ii) as relações sociais são fontes de experiências satisfatórias, pois o pesquisador envolve-se com um extrato social de grande vigor intelectual; iii) o trabalho garante autonomia, independência financeira e segurança - o autor considera que apesar de não ser dos profissionais mais bem pagos, mas na condição geral do país, os rendimentos são dignos; iv) o trabalho mantém ocupado e ajuda a estruturar o dia a dia, "somos donos do nosso relógio", e, ainda, acrescenta que o modus operandi e os horários de trabalho causam inveja aos profissionais de empresas; v) o trabalho é moralmente aceitável, traz contribuição social - sob este aspecto, o autor demonstra certo desconforto, principalmente quanto à contribuição social; vi) é realizado de forma eficiente e leva a um resultado, tem utilidade - neste ponto o autor levanta a mesma questão do aspecto anterior.

Na seção seguinte, discutimos especificamente o campo de atuação do professor de Administração no Brasil, visando a estabelecer uma espécie de contextualização da pesquisa realizada.

\section{O campo da Administração no Brasil}

As iniciativas mais relevantes para o desenvolvimento e o treinamento em Administração no Brasil tiveram origem no âmbito do governo federal a partir de 1938, com a criação do Departamento Administrativo do Serviço Público (DASP) na capital federal (MATOS, BALBACHEVSKY, SAMPAIO et al., 2002). As primeiras escolas de Administração brasileiras surgiram em consequência da política desenvolvimentista adotada a partir dos governos de Getúlio Vargas (SERVA, 1992). Quanto à graduação em Administração, o início se deu em 1952, voltado à administração pública na Escola Brasileira de Administração Pública (EBAPE) da Fundação Getulio Vargas (FGV). Dois anos mais tarde, criou-se o primeiro curso de administração de empresas no país pela mesma fundação, a Escola de Administração de Empresas de São Paulo (EAESP). Essa necessidade apresentou-se em um momento em que o modelo de desenvolvimento requeria pessoal qualificado para gerir de modo eficaz os recursos públicos e os empreendimentos privados.

A origem dessas escolas ilustra muito bem o processo de institucionalização do campo: tal processo é marcado pela importação dos conhecimentos científicos que seriam reproduzidos e difundidos no país. Por meio de acordos e convênios com universidades americanas, com destaque para a Michigan State University e a University of Southern Califórnia, foram implantados os cursos com currículos elaborados por professores americanos, os quais tiveram papel determinante nos métodos e nas técnicas de ensino, instalando as bibliotecas com seus respectivos acervos importados (SERVA, 1992). Naquela época, a formação dos professores merecia destaque: depois de selecionados das áreas correlatas como Direito, Economia, Contabilidade, Engenharia, os profissionais recebiam treinamento prévio no Brasil e depois eram enviados aos EUA, como bolsistas, para cursar o mestrado em Administração. 
O início da pós-graduação também esteve vinculado à FGV. A partir de 1961, a EAESP iniciou o curso de pós-graduação lato sensu e o início dos cursos de pós-graduação stricto sensu ocorreu após regulamentação, em 1965, dos mestrados e doutorados no país (MATOS, BALBACHEVSKY, SAMPAIO et al., 2002): "O primeiro mestrado data de 1967 e foi oferecido na área de Administração Pública, pela escola do Rio de Janeiro. Em 1970, foram criados os mestrados em Controladoria e Contabilidade na Universidade de São Paulo (USP) e, em 1972, o de Administração de Empresas na Pontifícia Universidade Católica do Rio de Janeiro (PUC-Rio) (MATOS, BALBACHEVSKY, SAMPAIO et al., 2002). Já no nível de doutorado, apenas em 1975 instituiu-se o primeiro curso, na Faculdade de Economia e Administração da USP (FEA/USP), seguido pela criação dos cursos pela EAESP e pela EBAPE, esta com o primeiro doutorado em administração pública.

Nas últimas décadas, dois atores institucionais vêm exercendo papéis essenciais no campo científico da Administração no Brasil: a Capes e a Anpad.

A Campanha Nacional de Aperfeiçoamento de Pessoal de Nível Superior (atual Fundação Capes) foi criada em 11 de julho de 1951, mediante o Decreto n. 29.741, com o objetivo de "assegurar a existência de pessoal especializado em quantidade e qualidade suficientes para atender às necessidades dos empreendimentos públicos e privados que visam ao desenvolvimento do país". A partir de 1966, com os planos de desenvolvimento marcantes do governo federal na área educacional, houve a reforma universitária, a reforma do Ensino Fundamental e a consolidação do regulamento da pós-graduação. Com a reformulação das políticas setoriais, com destaque para a política de Ensino Superior e para a política de ciência e tecnologia, a Capes ganha novas atribuições e meios orçamentários para ampliar suas ações e contribuir decisivamente para a qualificação do corpo docente das universidades brasileiras. Em 1981, pelo Decreto n. 86.791, a entidade é reconhecida como órgão responsável pela elaboração do Plano Nacional de Pós-Graduação Stricto Sensu.

Outro ator institucional foi decisivo para a implementação das políticas públicas elaboradas pela Capes, particularmente no campo científico da Administração: a Anpad. Criada em 1976, a partir da iniciativa dos oito programas de pós-graduação existentes no Brasil até então, a Anpad é hoje o principal espaço formal de interação entre programas associados, grupos de pesquisa da área e seus atores. O crescimento considerável de cursos de pós-graduação ofertados fez com que a Anpad reunisse em 30 anos mais de 60 programas associados em uma comunidade acadêmica que representa institucionalmente a pós-graduação em Administração no Brasil.

Serva (1992) destaca que, em geral, as escolas de Administração mantiveram por muitos anos os currículos e objetivos da década de 1950, não atentando para a realidade nacional. Nos últimos anos, a pós-graduação stricto sensu experimentou um crescimento extraordinário: dos 8 cursos de pós-graduação em Administração autorizados em 1976, passamos, atualmente, para cerca de 100 programas recomendados pela Capes. Destaca-se nesse ponto, também, a evidente diferenciação na política de recursos humanos, a saber, as mudanças nas exigências aos professores, principalmente a titulação e a produção/publicação científica. Essas transformações aceleradas geraram uma diversidade de situações profissionais e de condições de trabalho consideráveis e extremamente desafiadoras para os atores do campo. Enquanto nas primeiras gerações de professores valorizava-se a experiência prática, passou-se a valorizar mais a experiência como pesquisadores.

Em uma pesquisa sobre a pós-graduação no Brasil publicada pela Capes (VELLOSO, 2002) há um capítulo sobre os destinos profissionais de mestres e doutores em Administração. Nesse capítulo, algumas informações são divulgadas para contextualizar a questão da pós-graduação em Administração no Brasil. É interessante perceber que a formação acadêmica dos mestres é diversificada, sendo a maioria proveniente de outras áreas de base, ou seja, na graduação. A pesquisa apresenta outros dados sobre os mestres: predominância do sexo masculino; ingressaram no mestrado, em média, 7 anos após a conclusão da graduação; $84 \%$ já trabalhavam, a maioria em empresas, principalmente privadas, uma parcela menor na administração pública e somente 15\% em instituições de Ensino Superior; poucos tinham envolvimento com atividades de pesquisa; a motivação principal era o aumento de competitividade no mercado de trabalho e 
intenções outras, como a futura docência no Ensino Superior e a carreira de pesquisador eram menos ou até bem menos importantes (MATOS, BALBACHEVSKY, SAMPAIO et al., 2002). O estudo também revela que, dentre os doutores, $81 \%$ informaram que a decisão de cursar um doutorado foi influenciada pelo desejo de seguir ou ascender na carreira docente. Já dentre os mestres, apenas metade foi influenciada por esse objetivo, e $70 \%$ indicaram que a influência consistia no aumento da competitividade que o curso proporcionaria. Portanto, constatou-se que a carreira acadêmica e de pesquisador é característica predominante do curso de doutorado. No curso de mestrado, proporcionalmente, esse desejo pela pesquisa é menor e o objetivo é mais voltado à competitividade no mercado de trabalho, à empregabilidade. Quanto aos salários, a pesquisa apresenta que as empresas pagam melhor que o Ensino Superior, tanto para mestres como para doutores, nas seguintes proporções: $50 \%$ e $30 \%$ a mais, respectivamente.

Como vimos, o foco da discussão promovida neste artigo é o conteúdo do trabalho do professor-pesquisador em Administração no Brasil. Essa configuração profissional, com suas exigências, ritmo de trabalho, formas específicas de reconhecimento, de avaliação (notadamente marcada pelo controle externo da Capes) e de legitimação se distingue visivelmente da antiga configuração profissional do docente que não atua em programas de pós-graduação stricto sensu. A reflexão sobre as condições que cercam o trabalho do professor-pesquisador vem sendo expressa por meio de alguns estudos em nosso país, dentre os quais reportaremos alguns que oferecem, em seu conjunto, um bom delineamento do campo que ora abordamos.

Mattos (2008, p. 144) levanta a questão da pressão institucional por publicação. Inicia seu estudo tratando do processo de avaliação da Capes:

Quem acompanhou de perto esse processo nos últimos dez anos, desde que foi feita a mudança decisiva na sistemática de relatórios e mapas, que inclui, no último triênio, grande avanço da informatização, sabe o que não aparece sob os atuais resultados - o que de fato significam na vida dos programas e na agenda de trabalho de cada pesquisador. À flor da pele, está a pressão institucional por publicação [...] as aulas e orientação de alunos não valem nada na pontuação feita pelo Sistema Capes.

O autor constata, ainda, que o sistema atual de avaliação acadêmica da Capes "não tem como diferenciar a produção criativa da produção em escala, e receia-se que, por isso, acabe por dar guarida à segunda" (MATTOS, 2008, p. 149). O autor demonstra uma grande preocupação com a lógica que comanda a produção científica, pois "desvirtua-se a produção em equipe para multiplicar os créditos individuais de pontuação de cada um dos quatro ou mais autores (que, não raro, trocam amabilidades com a atribuição recíproca de autoria)" (MATTOS, 2008, p. 149).

Wood Júnior (2005) traz algumas evidências sobre a qualidade da produção em Administração, tendo como base sua experiência como editor de uma das revistas mais importantes na área no Brasil, a Revista de Administração de Empresas (RAE), da FGV. O autor informa que: i) apesar das 350 submissões anuais, completar uma pauta trimestralmente, com 7 ou 8 artigos, é uma tarefa árdua; ii) há dificuldade para dar continuidade a fóruns temáticos, pela falta de artigos em condições de qualidade para completar as seções especiais; iii) apesar da apuração quanto aos avaliadores e aperfeiçoamento do processo de avaliação blind review, "muitos artigos eram publicados sem condições para publicação, condições mínimas, apresentando problemas quanto à teoria, à metodologia, à contribuição científica, limitadas". O autor conclui que a produção nacional está a grande distância da produção dos centros de referência, em especial quanto à consistência e ao rigor.

A produção acadêmica transformou-se em sinônimo de fazer pontos, assemelhando-se a uma política análoga à lógica empresarial, na qual o que vale é a produtividade mensurada em números (ALCADIPANI, 2011a). Esse processo tem sido denominado "produtivismo" por alguns pesquisadores, em uma tomada de posição crítica ao sistema oficial de avaliação. Na medida em que o sistema de avaliação estabelece métricas em bases quantitativas, as práticas que legitimam ou não determinado indivíduo como apto para lecionar e orientar em programas de pós-graduação stricto sensu são comparadas ao sistema de produção industrial em 
série: "Trata-se da imposição da lógica do tempo empresarial taylorista-fordista em algo que é essencialmente artesanal" (ALCADIPANI, 2011a, p. 347).

Ainda sob esse ponto de vista, Alcadipani (2011a; 2011b) e Freitas (2011) discutem a inserção da lógica gerencialista no mundo acadêmico. Para Freitas (2011), a lógica taylorista se dá desde a escolha de uma única e melhor forma de avaliar todas as áreas de conhecimento até o modelo de avaliação que impõe o que deve ser observado e contribuir para a supervalorização da produtividade acadêmica, o que chama de "reino do irrelevante metodologicamente correto" (FREITAS, 2011, p. 1160). A autora ainda aponta alguns problemas dessa lógica: i) são reduzidos da rotina, graças a sobrecarga de trabalho, o espaço para leitura e reflexão, fundamentais aos professores-pesquisadores; ii) vale apenas aquilo que está por ser feito, o passado e a trajetória são invalidados; iii) a lógica da construção coletiva da ciência versus a avaliação individual; iv) algumas estratégias de sobrevivência: conluios para publicação; alianças estratégicas dos coautores; roubos e plágios de ideias de colegas e alunos; v) obrigação aos orientandos de apontar coautorias indevidas. Alcadipani (2011b, p. 1174) trata dos efeitos do produtivismo no mundo da pesquisa e também no âmbito da formação dos alunos da graduação, criticando a produção desenfreada de diplomados, por meio de "cursos enlatados, professores mal remunerados e livros-texto de baixa qualidade a rodo". Para o autor:

O produtivismo acadêmico impera. Viramos gestores de projetos, burocratas de papers. A formação vem sendo cada vez mais esquecida, o objetivo é produzir ainda que sem formação ou conteúdo. Muitos estão adoecendo com este sistema. Mede-se, apenas, quantidade de produção acadêmica. A qualidade ficou de lado. Há dez anos o problema está claramente diagnosticado. As explicações também estão dadas: invasão do gerencialismo na produção científica, cópia mal feita de modelos estrangeiros, sem falar da Capes, o nosso grande bode expiatório. O que mais há para ser dito a respeito disso? (ALCADIPANI, 2011b, p. 1176).

Faria (2011), ao abordar o aspecto político do campo, aprofunda a compreensão dos antecedentes e as implicações do produtivismo acadêmico na área da Gestão, por meio de uma perspectiva histórica e geopolítica das suas origens. $\mathrm{O}$ autor provoca reflexões para o posicionamento dos atores em relação a esse fenômeno, mostrando a importância da construção da governança da área para os debates sobre o produtivismo acadêmico, pois, segundo o autor, essa governança é liderada por instituições euro-americanas. Discute-se, assim, o produtivismo também a partir de questões históricas, políticas e internacionais.

Além da produção científica, na pós-graduação em Administração no Brasil, os professores-pesquisadores envolvem-se em diversas atividades. Essa diversidade de atividades enquadra-se dentro dos eixos da universidade pública no país: pesquisa, ensino e extensão. Existem, ainda, as atividades de gestão e as burocráticas relacionadas aos cargos (TEIXEIRA, OLIVEIRA, TAVARES et al., 2012), o que impõe limites à produção científica.

A partir das críticas elaboradas por pesquisadores de diversas áreas, Faria, Baibich-Faria e Zorzetto Filho (2008) discutem os fatores que influenciam as condições e a satisfação em relação ao trabalho dos docentes em programas de pós-graduação em Administração. Os autores identificaram 6 elementos constitutivos que influenciam a capacidade de trabalho e a satisfação com e no trabalho, sendo 5 com relação direta: sentimentos positivos; satisfação com o desempenho pessoal e com as atividades; satisfação com a vida sexual; disposição para o trabalho; prazer em trabalhar; e, finalmente, um elemento com relação inversa: o desconforto psicológico. Porém, o que mais preocupa os autores é que a neurose da produtividade docente foi "internalizada de forma inconsciente e impermeável à crítica" (FARIA, BAIBICH-FARIA e ZORZETTO FILHO, 2008, p. 13).

Verifica-se, portanto, um posicionamento crítico dos próprios pesquisadores em relação ao sistema pelo qual são medidos e que impõe uma lógica ao fazer científico. Desse modo, constata-se uma insatisfação séria no campo com respeito aos princípios que deveriam reger a produção científica dos pesquisadores. 
A seguir, reportamos as escolhas e soluções metodológicas que guiaram a realização desta pesquisa.

\section{Procedimentos Metodológicos}

A pesquisa que gerou este artigo é de natureza qualitativa e pode ser considerada descritivo-interpretativa. Trata-se de um estudo exploratório, uma vez que o tema, malgrado sua importância para a formação de professores-pesquisadores em Administração, ainda não teve o devido tratamento no Brasil, principalmente sob a ótica da sociologia da ciência. Na coleta de dados, foram entrevistados 6 professores-pesquisadores, com maior interesse na reflexão sobre a realidade efetivamente vivida e sentida pelos entrevistados que na generalização de suas percepções a outros atores do campo em questão.

Quanto à escolha dos entrevistados, procuramos diversificar os profissionais levando em conta diferentes características, como: i) tempo de serviço, incluindo professores jovens, professores com longa trajetória e 1 professor aposentado; ii) cargos e funções administrativas, incluindo 2 coordenadores ou ex-coordenadores de cursos de mestrado e/ou doutorado, por exemplo; iii) e, por fim, participação em grupos de pesquisa, incluindo professores que coordenam ou que apenas participam de grupos ou redes de pesquisa. Os professores-pesquisadores entrevistados fazem parte de programas de pós-graduação em Administração stricto sensu do Sul do país, sendo 3 de uma universidade federal e 3 de uma universidade estadual. Optamos por não divulgar os nomes das universidades e dos programas, com o objetivo de manter sigilo e anonimato em relação aos entrevistados.

Sobre a formação acadêmica dos entrevistados, 4 possuem graduação em Administração, sendo que 1 cursou outra graduação simultaneamente ao curso de Administração e 1 já havia concluído um curso de graduação diferente antes de iniciar o bacharelado na área; 2 entrevistados possuem graduação em outras áreas, sendo 1 em Comunicação Social e 1 em Engenharia. Apenas 1 possui toda a formação (graduação, mestrado e doutorado) em Administração, sendo que os demais tiveram formação e titulação em outras áreas afins, como engenharia de produção, por exemplo. De modo análogo, 1 dos entrevistados concluiu toda a sua formação em áreas fora do domínio da Administração, embora relacionadas às ciências sociais. Quanto à experiência profissional anterior, 4 trabalharam em empresas e apenas 1 seguiu para o mestrado logo após a conclusão da graduação. Já na carreira acadêmica, a maioria atuou como professor em mais de uma universidade: 2 começaram a lecionar em outras áreas antes de optar pela carreira de professorpesquisador em Administração. Especificamente em relação à docência, 1 iniciou o mestrado logo após começar a lecionar em uma universidade para turmas de Administração, enquanto 1 começou a dar aulas durante o mestrado e 2 professores começaram a docência apenas depois de cursar o mestrado, sendo essas experiências iniciais geralmente em universidades particulares.

Essa diversidade de trajetórias dos pesquisadores trazem diferentes contextos para se discutir as categorias de análise em questão, mas ressaltamos que este trabalho exploratório da agenda e do cotidiano do professorpesquisador não tem por objetivo generalizações. Por isso, optamos por uma estratégia de pesquisa com entrevistas em profundidade com um número reduzido de entrevistados para que se pudéssemos dar o tratamento de dados adequado, tendo em vista o objetivo da pesquisa de aprofundar a compreensão do conteúdo do trabalho do professor-pesquisador em Administração. Ainda que se tenha boa diversidade de trajetórias, reconhecemos que estas não correspondem à totalidade de trajetórias construídas pelos muitos atores do campo. Não obstante, como se trata de professores-pesquisadores inseridos em universidades públicas e, nestas, inseridos em programas de pós-graduação em Administração stricto sensu reconhecidos oficialmente pela Capes, tais profissionais são submetidos aos mesmos tipos de exigências gerais que os demais professores-pesquisadores em Administração no Brasil, notadamente aqueles que trabalham em universidades públicas (a Anpad, em seu quadro de associados, conta com 43 programas pertencentes a universidades públicas situadas em vários estados da federação).

A coleta dos dados primários foi desenvolvida por meio de entrevistas semiestruturadas e em profundidade com professores-pesquisadores de duas escolas superiores de Administração. Para a coleta dos dados, duas 
categorias foram utilizadas como norteadoras da análise, geradas a partir dos objetivos e da fundamentação teórica deste estudo, como mostra o Quadro 1.

Quadro 1

Categorias de análise

\begin{tabular}{|l|l|}
\hline Categorias de análise & Elementos constitutivos \\
\hline \multirow{3}{*}{ Objetivos profissionais } & Início da carreira \\
\cline { 2 - 2 } & Atuais \\
\hline \multirow{3}{*}{ Cotidiano } & Rotina \\
\cline { 2 - 2 } & Distribuição do tempo \\
\cline { 2 - 2 } & Agenda \\
\hline
\end{tabular}

Fonte: Elaborado pelos autores.

A categoria objetivos profissionais teve como embasamento teórico Bourdieu (1976; 1994; 2004a; 2004b), com extensão às dimensões de prestígio elaboradas por Leclerc (2005) e às dimensões de Louvel (2005). A categoria cotidiano está relacionada à construção da agenda do professor-pesquisador. Sua discussão está fundamentada principalmente no estudo de Berry (1995) sobre a agenda do pesquisador em um centro de gestão na França. Além da análise de dados guiada pelas categorias de análise, também utilizamos o programa NVivo 9 para pesquisa qualitativa. No NVivo 9, inserimos as transcrições das entrevistas para o programa, sources, e, posteriormente, foram classificados os nodes de acordo com os elementos constitutivos das categorias descritas acima. Posteriormente, criamos alguns queries, com a ferramenta de word frequency e, assim, foram criadas Tag Clouds. Por conseguinte, o emprego do programa citado foi importante para a categorização dos dados, bem como gerou insights para a análise.

\section{Análise dos Dados}

Esta seção discute os dados coletados de acordo com as categorias de análise expostas anteriormente. Por conseguinte, esta seção está subdivida em dois tópicos: objetivos profissionais e cotidiano.

\section{Objetivos profissionais}

Nesta categoria de análise, tratamos dos objetivos profissionais no início da carreira e dos objetivos atuais, finalizando com um tópico sobre o alcance desses objetivos.

Para alguns entrevistados, no ponto de partida os objetivos que os levaram a decidir pela carreira acadêmica eram claros; para outros, as coisas aconteceram gradualmente. Para o Entrevistado 1, por exemplo, o objetivo "era entrar na universidade e seguir uma carreira de professor e pesquisador", já para o Entrevistado 6 a adoção da carreira foi um processo que se desdobrou paulatinamente: "Eu não tinha um projeto de ser professor. Isso veio ao longo da vida". No entanto, ficou evidente que fazer o que se gosta foi um fator determinante na escolha da carreira. 
Dentre os entrevistados, 4 trabalhavam em empresas antes de seguir a carreira acadêmica; foram, então, motivados pela vocação e pelas características específicas da profissão:

Eu tinha um ótimo salário. Trabalhava numa empresa que todo mundo queria trabalhar, uma empresa pública, federal. [...] Quando optei por sair e encarar a vida acadêmica foi uma felicidade muito grande. Eu sabia o que eu estava deixando pra trás e sabia porque estava fazendo isso: fazer o que eu gosto. (Entrevistado 5)

Quanto às características da profissão, a que mais se destacou foi continuar estudando. Para o Entrevistado 1, "essa coisa de ficar sempre estudando, renovando os conhecimentos e renovando também as pessoas que tu conheces é muito legal, te renova". No mesmo sentido, o Entrevistado 3 afirma que a primeira questão era encontrar uma profissão em que fosse possível continuar a estudar. Outra razão apresentada pelo pesquisador foi a possibilidade de influenciar outras pessoas a crescer: "Eu tenho uma profissão que ao meu redor vejo as pessoas crescerem, e isso é muito positivo. Então, eu creio que são duas questões que com essa profissão eu consigo fazer e isso me agrada muito" (Entrevistado 3).

Outra característica da profissão que se enquadrava no objetivo pessoal foi referente ao desejo de viajar muito, saber andar pelo mundo e de conhecer o mundo. Um dos entrevistados afirmou que quando vislumbrou que isso era possível na carreira pelas possibilidades de congressos, estudar fora, participar de redes internacionais, por exemplo, e sabendo que como administrador não seria viável, já que "o dia a dia do administrador me prendia muito" (Entrevistado 5), isso teve influência na escolha.

Outro objetivo, levantado pelo Entrevistado 2 era uma meta bem clara: "Contribuir com a sociedade, fazer coisas que pudessem melhorar a vida das pessoas, coisas que fossem úteis". De forma geral, percebe-se que o papel de influenciar pessoas, defender uma causa, além de gerar conhecimento, características da profissão, proporcionou que esta fosse escolhida. Defender uma causa também emergiu na fala do Entrevistado 4, o qual buscava defender com mais consistência a causa que defendia, além de ter a influência clara de um orientador, em que viu com clareza a possibilidade de coerência.

Portanto, constata-se a existência de objetivos pessoais fortes na escolha dos professores-pesquisadores entrevistados, aliada à possibilidade de atingir tais objetivos nessa carreira. Assim, parecem ter sido decisivos os interesses pessoais e determinadas características da profissão na decisão dos professores. No que diz respeito aos objetivos atuais dos professores-pesquisadores, seguem em ordem decrescente os temas e o respectivo número de entrevistados: escrever, produzir (5), ser reconhecido (3), ajudar pessoas (3), qualidade de vida (1).

O Entrevistado 5 afirmou que, para ele, a questão do objetivo relaciona-se à autorrealização, significando construir e divulgar o conhecimento acumulado ao longo do tempo, sistematizar, fazer ligações, dar sentido ao resultado, e o objetivo principal é disponibilizar esse conhecimento para as pessoas:

O que eu mais quero hoje em termos de objetivo nessa nova etapa, não é expandir, agora é sistematizar e escrever, produzir, mas não é produzir por produzir, para fazer pontos, é gerar conhecimento bom e que valha a pena tê-lo acumulado durante todo esse tempo.

Para esse entrevistado, a publicação é um meio de obter reconhecimento pela sua obra, fazer um nome conhecido e reconhecido, o que está diretamente relacionado ao capital simbólico na abordagem de Bourdieu (1994).

O reconhecimento pelos pares também foi um objetivo que se repetiu nas falas dos entrevistados. Segundo o Entrevistado 1, "todo professor pesquisador tem o objetivo de ser reconhecido. $O$ reconhecimento, a realização, ver que a pesquisa contribuiu para alguma coisa, para o ensino". O Entrevistado 3, corroborando essa afirmação, proferiu que um dos seus objetivos atuais é escrever e obter o reconhecimento 
em seu meio acadêmico como alguém que produziu algo interessante. Esse reconhecimento, referente ao capital simbólico, é produto do reconhecimento dos concorrentes (BOURDIEU, 1994).

O Entrevistado 3 afirmou, também, que continuar influenciando pessoas é um de seus objetivos e realização, ver as trajetórias de seus alunos. Nesse aspecto, o Entrevistado 1 afirmou que "uma coisa muito legal é ver os teus alunos crescendo. Ajudar a formar pessoas, e se tu tens o gosto pela coisa e consegue passar isso para os alunos, acaba mostrando uma oportunidade para eles". Para o Entrevistado 2, ajudar pessoas é um dos objetivos atuais, contribuir de alguma forma. Nesse sentido, ajudar pessoas implica contribuir para sua formação, influenciar, discutir.

Gostaríamos de ressaltar uma observação do Entrevistado 2 sobre os objetivos: esse professor considerou complicado tratar em separado os objetivos pessoais e profissionais, já que, na sua visão, as duas ordens de objetivos se intercalam. O professor chamou a atenção para o objetivo de desenvolver-se em um tema, o qual considera importante na sua área. Fazer as escolhas de temas e liderar um tema é uma estratégia dentro do campo, nessa luta pelo acúmulo de capital científico (BOURDIEU, 1976; 1994), chegar antes pode significar ter mais "lucro", nesse caso, significando o reconhecimento (LECLERC, 2005).

Percebe-se que, ao longo da carreira, os objetivos profissionais do professor-pesquisador vão se alterando. Aos professores com menos tempo de carreira, ficou claro que querem se aprofundar em um tema, querem conseguir seu espaço na instituição de ensino onde atuam. Significa, sobretudo, tomada de posição no campo (BOURDIEU, 2004a). Para os que já estão mais estabelecidos, é ser reconhecido, e para os que já têm mais tempo, é sistematizar o conhecimento adquirido. No entanto, escrever e produzir estiveram presentes na maioria das entrevistas, relacionados aos outros objetivos. Destaca-se que apenas um único entrevistado trouxe a questão da qualidade de vida aliada aos outros objetivos profissionais, e colocou-a em primeiro lugar na sua carreira hoje.

No que concerne ao alcance dos objetivos, o Entrevistado 6 considera a questão da realização de objetivos "um pouco difícil", já que "emprego é forma como você vai ganhar a vida; contudo, do ponto de vista da realização pessoal a universidade é um dos melhores lugares para se trabalhar", mas, mesmo assim, devido às demandas, é preciso fazer coisas de que não se gosta: "Ser coordenador de mestrado, chefe de departamento, eu fiz, mas não gosto" (Entrevistado 6). O professor justifica: "São coisas que te tiram muito tempo, te incomodam muito, te criam muito desgosto, você se indispõe com algumas pessoas, sem querer você acaba tendo problemas" (Entrevistado 6). Quanto às atividades desempenhadas, além de uma questão pessoal de gosto, dois aspectos merecem destaque nessa colocação do pesquisador. A primeira diz respeito a se indispor com algumas pessoas e isso é considerado problemático em uma carreira na qual seu avaliador é seu par e a habilidade política é necessária para que se consiga acúmulo de capital científico puro. Seu concorrente é, ao mesmo tempo, seu colega nessa luta (BOURDIEU, 1994). O segundo aspecto está relacionado ao emprego do tempo, sendo necessário privilegiar atividades que gerem mais capital científico puro, já que o capital científico relacionado a cargos - o capital temporal - passa com os cargos (BOURDIEU, 2004a). Mesmo assim, existem aqueles que se dedicam a uma carreira mais próxima de cargos e poder no campo, estabelecendo estratégias de acúmulo desse tipo de capital.

Para o Entrevistado 3, o alcance dos objetivos "é a melhor parte, é o que a gente tem de bom aqui". O Entrevistado 2 afirma que exercer uma profissão "sofrível" sem vê-la como um caminho para a autorrealização não é possível, e afirma, ainda, que essa é uma profissão que permite a você ajudar muitas pessoas, o que é, além do alcance de objetivos, uma das vantagens da profissão.

No que concerne aos objetivos, cabe aqui uma importante ressalva em relação ao posicionamento de Pierre Bourdieu. A forte influência dos objetivos estritamente pessoais indicados pelos professores-pesquisadores na decisão de ingresso e no início de suas carreiras, bem como a indicação de aspectos ligados a objetivos acrescentados ao longo de suas trajetórias, tais como autorrealização, ajudar pessoas, continuar estudando, disponibilizar conhecimento, defender uma causa, viajar pelo mundo nos leva a estabelecer neste estudo um contraponto a um importante pressuposto de Bourdieu (1994): para esse autor, não há escolha que não seja uma estratégia política de obtenção do lucro científico; o autor considera o campo científico como uma 
estrutura determinante dos movimentos dos atores, estes denominados pelo autor agentes. Ainda que a maximização do lucro propriamente científico possa ser constatada na composição dos objetivos dos pesquisadores entrevistados, em nosso estudo o campo não se revelou uma estrutura totalmente determinante de suas ações.

Quanto às vantagens, a Entrevistado 5 trouxe o maior número de informações, inclusive condensando pontos que foram tratados em outras entrevistas, mas trazendo outras informações que se relacionam também à questão dos objetivos. Primeiramente, para esse professor-pesquisador, quando se opta pela carreira a questão vocacional é inegável e o objetivo principal é gerar conhecimento. E gerar conhecimento "dá uma sensação, um sentimento de autorrealização grande; você está criando" (Entrevistado 5). Esse entrevistado explica que isso se dá de duas formas, principalmente: "A primeira é que as pessoas aproveitam o seu trabalho" (Entrevistado 5). Conforme o tempo passa, percebe-se que o trabalho contribuiu para o avanço do conhecimento como um todo,

[...] pouco é verdade, mas sua contribuição está lá e se hoje gente mais jovem que você, por exemplo, e outras pessoas estão tendo a condição de fazer certos bons trabalhos é porque você fez um que eles utilizam como base. (Entrevistado 5)

A outra vantagem é a questão do campo, "entre os pares", que se explica da seguinte maneira:

O reconhecimento mútuo, o status, isso vai de alguma forma se encontrar com a autorrealização também, você ser reconhecido pelos colegas é algo que é muito agradável. Quem está na profissão com você reconhece que você gera conhecimento, agrega. Então, essa é uma vantagem grande. É o que motiva mais, essa é a verdade. Tem a questão interior e tem a questão social. Quem tem boa formação, trabalha em boas escolas diz pra você que seu trabalho é importante, então, você tem um status dentro de um grande sistema de representações sociais: aqueles que são considerados bons profissionais. (Entrevistado 5)

O pesquisador conclui que não há nenhuma vantagem material no Brasil e "você não tem ganhos materiais" (Entrevistado 5), enfatiza-se, então, a presença do capital científico, mais uma vez, por meio do reconhecimento pelos pares. Ressaltamos que, apesar de não se converter diretamente em ganhos materiais, como disse o pesquisador, dentro da carreira é o capital científico acumulado que possibilitará conversão no capital financeiro, como, por exemplo, a obtenção de bolsas, a aprovação em editais etc. (BOURDIEU, 2004b).

Pelos depoimentos dos entrevistados, podemos inferir que os aspectos sociais da profissão são de importância crucial para a carreira do professor-pesquisador. A importância da dimensão social reforça a noção de campo científico, pondo em destaque sua dinâmica. Essa constatação condensa uma série de elementos importantes para a análise sociológica da ciência: i) a noção de que há essa dinâmica social; ii) a noção de disputa pelo reconhecimento dos pares; iii) a noção de que seus colegas são, ao mesmo tempo, seus concorrentes; iv) a noção do que é levado em conta como critério para ser considerado um bom profissional é construída no campo; v) a questão de que o acúmulo de capital passa, também, pela dimensão institucional, tanto no que concerne à instituição de formação do pesquisador como às instituições onde ele atuou e atua. Subjacentes ao processo de construção de conhecimento estão esses elementos, em maior ou menor grau, a depender da trajetória de cada pesquisador. Com esta análise, não se almeja enfatizar qual deles é o mais importante, mas, sim, demonstrar a diversidade de elementos que subjaz à dinâmica do campo, ressaltando, assim, sua complexidade.

$\mathrm{Na}$ próxima seção, analisamos a prática científica dos pesquisadores como uma contribuição para a compreensão do campo no nosso país. 


\section{Cotidiano}

Primeiramente, é importante destacar que no cotidiano dos professores-pesquisadores há muito poucas atividades com horários fixos; "eu não tenho uma rotina" (Entrevistado 3). Além disso, cada agenda é diferente das outras, pois são moldadas em relação às funções assumidas na instituição de ensino por cada profissional. Ressalta-se que lecionar é uma das poucas atividades que demandam um horário fixo na agenda semanal do professor. Neste tópico são abordadas as atividades dos professores-pesquisadores, a distribuição do tempo para essas atividades e a configuração geral das agendas.

Para melhor estruturar o tratamento das atividades que configuram a agenda do trabalho do professorpesquisador, classificamos suas tarefas em três grupos: atividades do professor; atividades do pesquisador; e atividades administrativas. Reconhecemos a arbitrariedade dessa classificação, uma vez que muitas atividades estão interligadas, contudo, tal classificação se mostrou útil e pertinente para analisar os dados coletados. No âmbito da sociologia da ciência, resgatamos, aqui, a classificação elaborada por Berry (1995) ao analisar a agenda dos professores-pesquisadores do CRG na França: a esfera das obrigações, a esfera das solicitações e a esfera criativa. Buscamos, em nossa análise, entrelaçar, quando possível, as duas classificações.

Antes de tratar de cada atividade, faz-se necessário enfatizar que as atividades são as mais variadas e, nesta pesquisa, constam dados informados pelos pesquisadores, portanto, essas informações vão além do que se encontra nos planos de trabalho ou no plano de atividades de cada professor junto à instituição, retratando as atividades em conformidade ao envolvimento informado pelos entrevistados. O Entrevistado 5, por exemplo, comentou as demandas formais e informais; cremos que essa perspectiva engendra uma visão mais "real" das atividades daquele profissional, uma vez engloba seu engajamento como um todo.

Com a aplicação do programa NVivo 9 aos dados coletados nesta categoria de análise, as palavras mais frequentes relacionadas às questões que tratam das atividades dos entrevistados foram as seguintes: professor, pesquisa e pesquisador, atividade, tempo, núcleo. Com o desmembramento entre as atividades do professor, do pesquisador e as atividades da esfera burocrática, será possível identificar as relações entre as palavras mais frequentes.

Para os entrevistados, as atividades associadas ao professor são aquelas relativas ao ensino: dar aulas, preparar o material para as aulas, elaborar sistemática de avaliação, corrigir as atividades, tanto de graduação quanto pós-graduação, orientar e atender alunos. Portanto, as atividades classificadas nesse grupo não se limitam ao horário fixo das aulas. Quanto ao ensino em si, para o Entrevistado 5, o bom professor é aquele que está atualizado, domina recursos pedagógicos e facilita a aprendizagem. Já o Entrevistado 1 vai além e expressa que a diferença entre o professor e o professor-pesquisador consiste em que o professor tomará por base textos de livros e, principalmente, a experiência profissional, enquanto o professor-pesquisador trará para as aulas, periódicos e conhecimento embasado em pesquisas. Outra atividade citada por alguns dos entrevistados como relacionada ao papel de professor é a orientação formal de trabalhos (trabalho de conclusão de curso, monografia, dissertação, tese); entretanto, para outros respondentes, essa atividade foi elencada entre aquelas de pesquisa. Segundo o Entrevistado 5, no campo acadêmico, essa atividade também é reconhecida como essencial para um bom professor. Os entrevistados 2 e 4 inseriram nesse grupo, ainda, atividades de atendimento extraclasse aos alunos, esclarecimento de dúvidas, orientação informal de trabalhos e recomendação de textos.

Ao analisar o grupo das atividades do professor, estabelecemos um paralelo com a esfera das obrigações (BERRY, 1995), as quais estão relacionadas ao cargo dentro da instituição e são marcadas por horários fixos. Por outro lado, lecionar em determinada instituição que tem uma posição de destaque no campo pode ser visto como uma fonte de prestígio para o profissional, de acordo com as fontes de prestígio elencadas por Leclerc (2005). 
No que diz respeito às atividades de pesquisa, segundo o Entrevistado 2, o pesquisador lê bastante, levanta dados, compreende aquilo que lê e sistematiza; tem encontros com seu grupo de pesquisa ou pares para discutir pontos de vista, debater questões; e publica os resultados das pesquisas. Sendo assim, além das atividades individuais, leitura, sistematização, há o envolvimento e a participação da comunidade científica. Para o Entrevistado 2, "o artigo deveria ser o resultado de todo esse trabalho de pesquisa, de dialogar com muita gente e depois você escrever e participar da comunidade científica". É fundamental a participação na comunidade científica, porém, mais que isso, o Entrevistado 2 reforça a necessidade de ter um grupo de pessoas na universidade para "extravasar um pouco das suas ideias e ter um retorno sobre o que você escreve". Quanto à participação em grupos de pesquisa, o Entrevistado 5 afirmou que

[...] o pouco apoio que há, no Brasil, é todo para quem está agrupado e participando de redes. Então, ele tem de atuar nesse nível também. Tem de participar de um grupo, núcleo, centro de pesquisa que seja atuante, não pode ser uma coisa só no papel.

O Entrevistado 5 enfatizou a necessidade de estudar, que enquadrou como uma atividade muito especial. Segundo o entrevistado, em tese, todo professor tem de estudar, mas o professor-pesquisador tem de estudar mais que o profissional que atua exclusivamente como professor. $\mathrm{O}$ pesquisador não pode parar de estudar $\mathrm{e}$ deve fazê-lo em um ritmo semelhante a um mestrando, a um doutorando, para ser um bom pesquisador e ser reconhecido como tal, enfim, para gerar conhecimento (Entrevistado 5).

O Entrevistado 3 entende que as atividades de pesquisa também incluem os grupos informais de estudo, os seminários e as atividades administrativas do grupo de pesquisa, as orientações, as leituras, a elaboração de artigos, a avaliação de artigos para periódicos e eventos, a avaliação de projetos de pesquisa de pares, fazer parte de comitês científicos. Quanto à orientação, optamos por enquadrá-la no grupo atividades do professor, como foi explicado na seção anterior, justamente por ser uma atividade vinculada à figura do professor, no entanto, como se percebe nas atividades listadas pelo entrevistado, não há um limite muito claro dessas atividades no cotidiano.

Outrossim, o Entrevistado 5 completa as atividades referentes à pesquisa:

Pesquisa envolve tudo isso, mas têm as questões da pesquisa mesmo, estudar, interagir, buscar o que está sendo feito na área, tem de ter um tempo que nem é leitura, do nada, de refletir sobre aquilo. Ele e os esquemas dele, seus papéis, parar e pensar naquilo que está pesquisando e você dar um balanço do que fez, para onde vai, o que está aprendendo com aquilo.

Então, resumidamente, o pesquisador é aquele que está necessariamente envolvido, participando ou coordenando um projeto de pesquisa. As atividades agregadas são: estudar, avaliar tanto periódicos e eventos como projetos; organizar ou participar de congressos e eventos científicos; e integrar ou coordenar grupos de pesquisa.

Quando o pesquisador se torna coordenador de um grupo de pesquisa, algumas funções adicionais lhe são atribuídas. Enquanto coordenador, ele "monta o núcleo e o conduz, então, ele é um gestor da pesquisa" (Entrevistado 5). O coordenador, ou líder de grupo ou centro de pesquisa, elabora os projetos, participa de reuniões para negociar seus trâmites e também de reuniões com outras instituições, representando o núcleo ou a universidade. Dentre as funções adicionais, o Entrevistado 5 citou as seguintes: captação de recursos e gestão de equipes. Quanto à captação de recursos, o pesquisador deve mapear onde estão as fontes de recursos e desenvolver a habilidade de responder aos editais das instituições de fomento à pesquisa. Na gestão da equipe, as atividades são referentes a comunicação, forma de lidar com pessoas, manter o grupo integrado, já que é um risco dos núcleos desenvolver pesquisas de maneira individual, tendo como coletivo apenas o ambiente físico e "não é porque é pesquisador que vai deixar de enfrentar os problemas que todo grupo produtivo enfrenta: conflitos, mal-entendidos, as pessoas têm expectativas..." (Entrevistado 5). Os 
desafios destacados são relativos ao perfil das pessoas que integram um grupo de pesquisa. São pessoas altamente qualificadas, encontram-se nos níveis mais altos dos estudos e do conhecimento e, nas palavras do Entrevistado 5, "são intelectuais e são exigentes, são pessoas que não querem ser somente 'tarefeiros', querem participar das decisões e têm opinião, têm uma visão, estudam". Em se tratando da atividade de coordenação de grupo de pesquisa, pudemos constatar a semelhança dos dados coletados em nosso estudo com os dados e a análise empreendida por Bini, Serva e Melo (2013): no desempenho dessa atividade destaca-se a pluralidade de tarefas assumidas e, também, seu grau de complexidade em conjunto, uma vez que parte das tarefas tem um cunho essencialmente técnico, como a captação de recursos, a gestão financeira e a consequente prestação de contas, enquanto outras tarefas requerem habilidades comportamentais que dizem respeito à gestão de pessoas qualificadas. Assim, torna-se evidente a pressão ampliada sobre a disponibilidade de tempo do professor-pesquisador, aumentando a complexidade que marca seu cotidiano.

Um dos entrevistados comentou que, ao longo da carreira, quando o pesquisador passa a se tornar mais conhecido por seu trabalho, ele recebe um nível de demanda muito alto, impacto gerado pelo alto capital científico. São demandas para palestras, muitas vezes viajando, para bancas, para avaliação de revistas:

Você estuda, produz, as pessoas leem o que você produz e você faz um esforço pra isso, pra se tornar conhecido, pra divulgar o que faz, é legal, mas tem a faca de dois gumes, começam as demandas. Pessoas que você nunca viu te mandam mensagem, e-mail, telefonam pedindo ajuda porque estão fazendo trabalho na área, são mestrandos, doutorandos, professores fazendo pesquisa. E também revistas, congressos que te chamam como avaliador, isso é uma coisa terrível. (Entrevistado 5)

No momento em que a demanda aumenta, o pesquisador tem de dizer "não" a algumas propostas de avaliação para revistas, por exemplo. Para o entrevistado, o pesquisador faz um julgamento próprio, avaliando quais são as revistas mais importantes, nas quais ele gostaria de publicar, as que atingem um público de uma região, ou um país, um estado, no qual tem maior interesse. No caso do Brasil, o entrevistado considera que a maioria pensa nas revistas mais lidas no Sul e Sudeste, no eixo central, Brasília, Rio de Janeiro e São Paulo, e um pouco mais o sul, que considera ser o centro da área.

Ele não vai dizer não a uma revista da Getulio Vargas, da USP, mas se a revista vier do Pará e não for muito conhecida, pertencente a uma instituição que não tenha muita fama, ele pensa, essa ele pode dizer não. O prejuízo teórico a dizer não a uma revista desse tipo é menor do que numa A. (Entrevistado 5)

“A” refere-se à classificação "Qualis A" da Capes, a mais alta atribuída a um periódico científico no Brasil. Aqui, fica clara mais uma estratégia para adquirir e maximizar o capital científico, de acordo com Bourdieu (1994).

Nas instituições pesquisadas, as atividades de pesquisa não devem ultrapassar $50 \%$ das atividades que constam nos planos de trabalho oficiais. A essa categoria relacionamos a esfera das solicitações indicadas por Berry (1995): os encontros de campo, demandas internas e externas, participação em bancas, avaliação para periódicos, avaliação de projetos de pesquisa requerida por agências de fomento e participação em comitês científicos. Ademais, é intrínseca a essa categoria a esfera criativa (BERRY, 1995): a participação em seminários, congressos e colóquios, os grupos de discussão, os estudos e a produção.

No tocante às dimensões de prestígio almejadas pelos intelectuais universitários e indicadas por Leclerc (2005), percebe-se que, na função de pesquisador, o profissional se aproxima de três categorias, de acordo com os dados levantados em nosso estudo: i) a primeira é relacionada a escrever uma obra e ter periodicidade na produção para aumentar a reputação como pesquisador; ii) a segunda é o papel de edição e 
avaliação da produção dos pares, como avaliador de periódicos, editais, comitês científicos; iii) além dessas, alguns partem para a direção de laboratórios, núcleos e grupos de pesquisa que é, para Leclerc (2005), outra fonte de prestígio.

Na visão geral dos entrevistados, as atividades do cotidiano até aqui comentadas são consideradas principais, mas agregadas a essas foram indicadas as atividades burocráticas, as quais o Entrevistado 5 denominou "penduricalhos". São atividades rotineiras e que, para o Entrevistado 5, roubam um tempo muito grande. Nesse grupo se encontram as tarefas de ordem administrativa, relacionadas à burocracia do campo acadêmico. Tais tarefas envolvem a participação em comissões de vários dimensões e temas, participação em reuniões, elaboração de relatórios de progressão, de pareceres em processos, e são ainda maiores quando se exerce atividades de coordenação ou se ocupa cargos na estrutura burocrática (entrevistados 3 e 5). Em muitos casos, nessas reuniões são tomadas decisões que influenciam diretamente o trabalho do professor e "por isso, ele tem de estar sempre muito informado, estar alerta às coisas" (Entrevistado 2).

Segundo o Entrevistado 5, principalmente quando se ocupa um cargo burocrático, a quantidade e a variedade de pessoas que procuram o professor-pesquisador é enorme; há os alunos que estão no programa e têm dúvidas ou querem tratar de assuntos burocráticos, bolsas, por exemplo, e os candidatos que querem ingressar no programa, esclarecer dúvidas sobre o processo seletivo etc. Além disso, "têm as demandas informais e se você estiver em um cargo vai enfrentá-las: resolução de problemas que se dá na negociação" (Entrevistado 5).

Como coordenador de um programa de pós-graduação, as atividades passam pela autorização de um curso, reconhecimento e a atualização desse reconhecimento, toda a parte do processo de seleção, todos os assuntos institucionais referentes à pós-graduação. De modo geral, o Entrevistado 1 explica que envolve

[...] toda parte de regulamentação da Capes, reconhecimento nos conselhos, relatórios da Capes, atender aluno, atender professor. De dezembro do ano anterior até abril do ano subsequente é complicadíssimo, tem que pensar no processo de seleção, preencher o Coleta Capes, mas são épocas. Fora isso, é um documento ou outro, acompanhar, não te toma o dia todo.

$\mathrm{O}$ atendimento, atividade citada pelo Entrevistado 5, referente às atribuições de coordenadores, envolve tarefas das quais não se pode escapar.

O Entrevistado 5 finalizou acrescentando algumas outras atividades burocráticas: responder documentos e participar das reuniões informais. Quanto aos documentos, constatou que a burocracia os envia, geralmente, com prazos apertados e

[...] tem que responder para o dia seguinte, precisa levantar dados, refletir, conversar com outras pessoas, mas a máquina não quer saber e principalmente se é uma coisa do seu interesse da sua área, se você não fizer amanhã, você perde, aí, o que vai fazer? Não pode deixar de fazer porque perde, você deixa tudo de lado e vai fazer aquilo. (Entrevistado 5)

Em se tratando das reuniões informais, esse entrevistado citou como exemplo as reuniões para negociação, já que não são formais, mas envolvem de modo direto o trabalho do pesquisador e, também, o trabalho do coordenador.

Ao analisar as atividades burocráticas à luz do estudo de Berry (1995), percebemos uma espécie de mix da esfera das obrigações (atividades específicas da instituição com a qual o pesquisador tem vínculo formal) e da esfera das solicitações (principalmente as demandas externas). Vale ressaltar que a ocupação de cargos é indicada por Leclerc (2005) como uma fonte de prestígio advindo do prestígio da instituição, ao passo que Bourdieu (2004a) vai denominá-la poder temporal ou político. 
Quanto ao segundo elemento constitutivo do cotidiano, distribuição do tempo, com base nas agendas ${ }^{4}$ elaboradas pelos entrevistados criamos o Quadro 2, um quadro geral das atividades, e o Quadro 3, que apresenta a agenda de uma semana média de professores-pesquisadores. Solicitamos aos pesquisadores que tentassem estimar uma agenda semanal típica de trabalho, todavia, o Entrevistado 1 nos deu um depoimento revelador: "A maior parte do ano não é normal. Abril teve Coleta Capes e tem Anpad, tem que fazer artigos. Óbvio que gostaria de ter mais tempo para pesquisa e para orientação. A atividade administrativa consome muito tempo". O Entrevistado 1 comenta, ainda, que a distribuição de tempo feita no plano de trabalho da instituição de ensino em que trabalha "é para inglês ver", pois não condiz com o tempo que dedica a cada uma das atividades e, sobretudo, porque leva trabalho para casa.

Vê-se claramente que a Capes e a Anpad são instituições que influenciam as práticas dos atores, exercendo uma força no campo científico em regulamentação, por exemplo. Reforçando o que foi abordado acima, os efeitos da ação dessas entidades no campo vão desde a influência sobre as escolas até o cotidiano dos professores-pesquisadores.

Com base nas agendas semanais de cada professor pesquisador - agendas médias estimadas -, elaboramos o Quadro 2, que apresenta as principais atividades empreendidas no campo.

Quadro 2

Quadro geral das atividades do professor-pesquisador
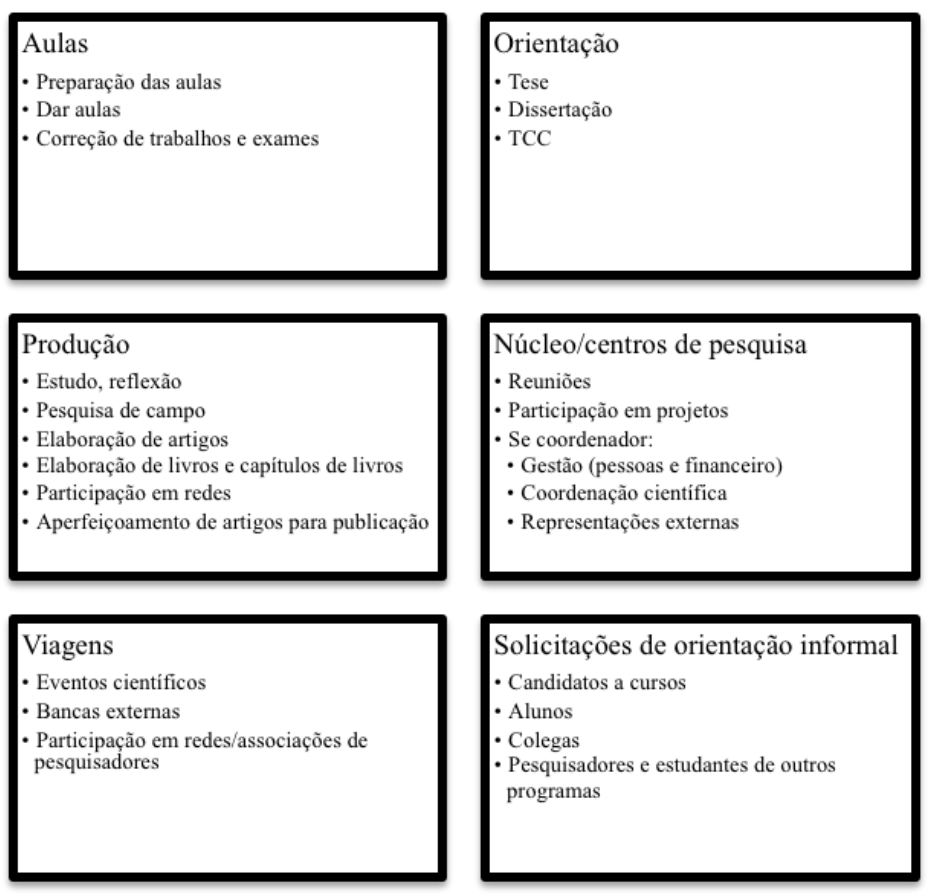
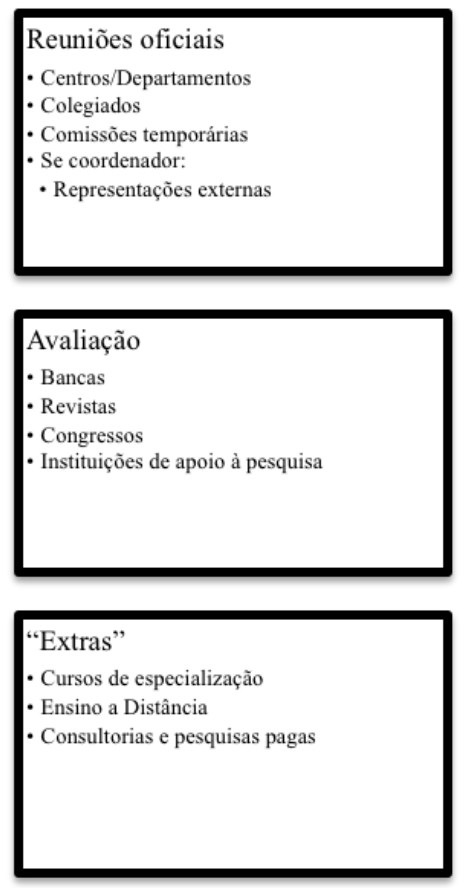

Fonte: Elaborado pelos autores.

Outra informação relevante que se deu durante o preenchimento das agendas foi a ocorrência de "extras". Os extras representam atividades para complementação de salário. Segundo o Entrevistado 5, "como professor ganha muito pouco, a remuneração é ruim em comparação com países em que a ciência é bem desenvolvida, ele, além disso tudo, tem de complementar a renda". Essas atividades não foram listadas nas atividades do professor- pesquisador, mas em duas agendas elas foram encontradas. Os extras, como denominados pelos

\footnotetext{
${ }^{4}$ Esclarecemos que não se trata de uma agenda precisa, e sim uma estimativa de uma semana normal/regular de trabalho de cada professor-pesquisador entrevistado.
} 
professores, são os cursos de especialização, os contratos de consultoria, as apostilas elaboradas para ensino a distância (EAD), palestras, enfim, são ganhos adicionais para compor a renda dos professores. O Entrevistado 5 afirmou que "no ano passado eu não aceitei nenhuma dessas atividades, mas, daí, o que a gente nota é que acaba faltando dinheiro [...] Não consegui pagar tudo que eu tenho para pagar".

Na visão do Entrevistado 2, faltou mais tempo para poder escrever, pensar, e também faltaram dias nos quais não houvesse atividades burocráticas, "dois dias inteiros, por exemplo". Quanto a essas atividades administrativas, o Entrevistado 4 comenta que "é muito triste estar num momento criativo e ter que participar de uma reunião burocrática". Para o Entrevistado 3, as atividades que entravam a pesquisa são: as atividades extras, as atividades administrativas e o ensino, quando é grande a quantidade de turmas e de alunos, prejudicando o amadurecimento e a reflexão que a pesquisa exige. Segundo o Entrevistado 5, se o professor negar a assunção de certas atividades em razão de estudar, fazer pesquisa, "ainda pode passar por preguiçoso". É preciso ter cuidado quanto a isso, na visão dele, porque hoje quem produz mais e produz melhor é quem se dedica mais a estudar, interagir no âmbito da pesquisa, quem vai aos bons eventos, mas "se você se deixar moldar, você acatar tudo que é colocado de tarefas, você se torna um professor mediocre, vai estudar muito pouco, vai fazer pouca pesquisa, vai refletir pouco sobre o que está fazendo e vai repetir coisas" (Entrevistado 5).

Destaca-se, finalmente, a síntese do último elemento constitutivo dessa categoria de análise, a agenda em si. No Quadro 3 transformamos os turnos em horas de trabalho e elaboramos então uma agenda média de um professor-pesquisador. Lembramos que a agenda média elaborada é apenas uma representação visual das atividades dos entrevistados, não sendo o fim em si desta pesquisa. A última linha apresenta a quantidade de horas de trabalho realizadas por dia para que seja possível desempenhar as atividades descritas pelos entrevistados. Esclarecemos que ao lado da descrição de cada atividade encontram-se as horas (em média) necessárias para realizá-la.

\section{Quadro 3}

Agenda semanal média do professor-pesquisador

\begin{tabular}{|c|c|c|c|c|c|c|c}
\hline & SEGUNDA & TERÇA & QUARTA & QUINTA & SEXTA & SÁBADO & DOMINGO \\
\hline $\begin{array}{c}\text { 崖 } \\
⿱ 亠 幺\end{array}$ & $\begin{array}{c}\text { PREPARAR } \\
\text { AULA }\end{array}$ & $\begin{array}{c}\text { PREP. AULA; } \\
\text { AULA PÓS- } \\
\text { GRADUAÇÃOO }\end{array}$ & $\begin{array}{c}\text { AULA } \\
\text { GRADUACCÃO; } \\
\text { ORIENTAÇÃO }\end{array}$ & $\begin{array}{c}\text { E-MAIL; } \\
\text { ADMINIST. }\end{array}$ & $\begin{array}{c}\text { REDES; } \\
\text { EXTRA; } \\
\text { AVALIAÇÃO }\end{array}$ & PESQUISA & PESQUISA \\
\hline H/DIA & 8 & 8 & 7,66 & 8,33 & 6,66 & 8 & 4 \\
\hline
\end{tabular}

Fonte: Elaborado pelos autores.

Verificamos uma carga de trabalho de aproximadamente 50,65 horas semanais. Sabe-se que uma carga de trabalho de 50 horas é muito elevada para uma semana. Essa agenda média mostra que $46 \%$ das atividades desses profissionais estão relacionadas ao ensino (lecionar, preparação de aula, orientação), $24 \%$ às atividades de pesquisa, $19 \%$ às atividades burocráticas, $8 \%$ avaliação de artigos e participação em redes e $3 \%$ às atividades extras. Outro dado importante é que $47 \%$ das horas despendidas com pesquisa são gastas nos finais de semana. Portanto, um dos trabalhos mais importantes da profissão é realizado fora da jornada regular de trabalho.

No trecho abaixo, um professor-pesquisador aponta algumas percepções que foram confirmadas nas agendas dos demais entrevistados:

Grande parte do trabalho que o professor-pesquisador leva para casa é o estudo. Quando ele deveria, eu acho, estudar dentro das suas horas de trabalho profissional. Ele acaba levando pra casa, no lazer, no fim de semana, nas férias, nas viagens. Então, por quê? Porque a 
atividade cotidiana, as organizações do mundo acadêmico no Brasil, principalmente, não levam isso em conta. Enchem o professor de tarefas, principalmente de ensino, e aí se ele disser para o departamento ou centro dentro da universidade que de tal hora a tal hora ele vai estudar, isso não conta, nem existe, nem é computado... como se estudar não fosse trabalho, e é o principal trabalho do professor-pesquisador, de todo professor, mas, principalmente, do professor-pesquisador. Geralmente deixam para o final de semana. Aí, entra em competição com o outro lado da vida. (Entrevistado 5)

Para o Entrevistado 3, "a carga elevada de trabalho prejudica tudo". E o Entrevistado 5 adiciona um aspecto agravante: "É um tipo de trabalho que não tem espaço físico, este é totalmente móvel", reforçando o que foi identificado por Dortier (2001). O pesquisador complementa:

O que se leva para casa e o que entra pela noite, em geral, é a produção própria, é o estudar, criar, o que talvez para o pesquisador fosse o mais importante e ele deveria, a meu ver, de segunda a sexta, bloquear turnos inteiros para isso. Dificilmente você encontra alguém que na semana típica tira um turno para somente estudar, as pessoas estão atendendo, respondendo, interagindo, mas não estão lendo, não estão fazendo sua reflexão. (Entrevistado 5)

$\mathrm{Na}$ agenda do Entrevistado 3, por exemplo, "tem dia que a gente não almoça", já que o meio-dia tem sido muito utilizado, "principalmente, para essas coisas operacionais: responder e-mails hoje consome pelo menos uma hora e meia a duas horas por dia". Após o preenchimento da agenda, esse entrevistado constata que a carga que hoje se tem dificulta um contato maior com a realidade profissional que se estuda, ressaltando a elevada carga de trabalho. E o aumento de carga de trabalho, principalmente quanto às atividades burocráticas, fez com que alguns pesquisadores se manifestassem enquadrando as posições de administração na universidade como "incômodas, tanto para o ensino quanto para a pesquisa" (Entrevistado 3). Essas manifestações confirmam as conclusões de Berry (1995) referentes à relação entre a carga de trabalho e a agenda.

$\mathrm{Na}$ organização da agenda, algumas atividades são priorizadas, geralmente as que provêm de demandas externas. O Entrevistado 1 citou que "na semana passada, por exemplo, a Pró-Reitoria de Pesquisa marcou reuniões e foram 3 dias na semana, e nos outros dias tens que dar conta das outras atividades". Para o Entrevistado 5, são as demandas de acordo com os pesos, primeiramente as da burocracia, depois as demandas externas de interesse do pesquisador, como "avaliar um artigo de uma revista de São Paulo, e isso faz esta passar na frente muitas vezes", mas existem, ainda, as demandas intempestivas, "têm atividades que vêm com um prazo apertadíssimo e parece que você está numa fábrica". Para professor-pesquisador, isso muda muito quando se assume cargos de coordenação, porque "o peso das demandas externas e não regulares é imenso" (Entrevistado 5). E, na visão desse entrevistado,

[...] as demandas vão triplicar com um cargo, claro que é uma estimativa. E como seu tempo é finito, você joga para fora um monte de coisas e aperta outras. Começa muito mais a responder a outras pessoas do que tocar seus planos de trabalho. (Entrevistado 5)

No que diz respeito às atividades consideradas mais importantes, o Entrevistado 2 afirmou que detesta reuniões formais e não as considera importantes; na visão dele, as atividades mais importantes são: dar aula, "se eu não vier dar aula, sou demitido", pesquisa, tempo de leitura. Além dessas, citou o e-mail como uma dessas atividades, já que, em sua opinião, é o canal de comunicação, é o meio pelo qual surgem oportunidades de pesquisa. Para o Entrevistado 6, são a sala de aula e a pesquisa. Para o Entrevistado 5, a sala de aula é inalienável e as atividades mais importantes são estudar, escrever, refletir e as ações de pesquisa. Nessas ações, elencou algumas atividades: entrevistar pessoas, coletar documentos, conversar com outros pesquisadores, atividades da pesquisa em si. O Entrevistado 5 conclui que "fora a sala de aula, o que é mais importante, em geral esse que é mais importante fica para um horário extra, um local extra". Dentre 
essas atividades - as importantes - foram destacadas aquelas relacionadas à esfera formal, a esfera das obrigações, e o que fica para o extra, à esfera criativa (BERRY, 1995), estas últimas são as que proporcionam capital simbólico na acepção de Bourdieu (2004a).

Já as atividades mais gratificantes para o Entrevistado 2 são: dar aulas no mestrado e as atividades como pesquisador, "em escala, primeiro é ler e escrever, segundo é esse encontro com pessoas, grupos de pesquisa, reuniões de ideias muito ligadas à criatividade e aula do mestrado". O Entrevistado 3 ressalta que o maior prazer encontra-se nas atividades em que sente que está aprendendo. O Entrevistado 5 tem como atividades mais gratificantes: estudar, escrever e produzir; para ele, "estudar para criar coisas é uma atividade que leva mais tempo, é longa, às vezes tem que se estudar por meses a fio para chegar num patamar interessante". Nessas atividades, aparecem fundamentalmente as atividades da esfera criativa (BERRY, 1995) relacionadas à pesquisa que proporcionam aprendizado e contribuem para a acumulação de reconhecimento pelos pares.

\section{Considerações Finais}

Os intelectuais contemporâneos, produtos das universidades, tornaram-se objeto de estudo para a sociologia da ciência. Neste estudo, partimos da perspectiva da sociologia da ciência para colocar o professorpesquisador no centro da investigação como elemento essencial para reflexão sobre o campo científico da Administração.

Por meio da análise dos dados coletados nas entrevistas em profundidade junto a 6 professores-pesquisadores de Administração, inseridos em universidades públicas do Sul do Brasil, foi possível aprofundar o conhecimento sobre o conteúdo de seu trabalho, ressaltando os objetivos que guiam suas trajetórias profissionais. A pesquisa promove a reflexão desses profissionais sobre seu cotidiano, sobre os desafios e entraves ao alcance de seus objetivos, mas ela também põe em destaque as razões de agir, as lógicas empregadas na organização de seu tempo de trabalho, a priorização das atividades na montagem de suas agendas e a indicação das atividades consideradas mais importantes e/ou prazerosas.

No tocante às atividades de pesquisa, constatou-se que o profissional deve se dedicar à leitura e à reflexão, fazer parte de uma comunidade científica e de comitês científicos de avaliação de artigos e projetos, e, além dessas atividades, investir tempo na participação em grupos e redes de pesquisa. Quando o profissional se envolve com grupos de pesquisa, pode assumir a coordenação destes, tornando-se, então, um gestor, e passa a desenvolver atividades complementares desafiantes, como as de captação de recursos, gestão de pessoas e representação do coletivo de pesquisa.

As aqui denominadas "atividades do professor" envolvem: planejar e ministrar aulas, preparar materiais didáticos, elaborar sistemas de avaliação de desempenho e de correção de trabalhos, orientação e atendimento aos alunos.

Os principais entraves mapeados são de natureza burocrática e compreendem a participação em reuniões formais e em comissões diversas, a elaboração de relatórios e de pareceres. Caso o profissional assuma um cargo burocrático, essas atividades se ampliam, com o atendimento de alunos, as reuniões informais para negociação e o tratamento de documentos diversos referentes à função que demandam respostas e/ou ações.

Quanto aos objetivos dos profissionais, ressalta-se que, no início da carreira, eles objetivavam, sobretudo, continuar estudando, seguir a vocação. Houve forte presença de objetivos pessoais nas escolhas, considerando as características típicas da profissão e interesses profissionais que poderiam ser alcançados. Atualmente, os objetivos concentram-se em produzir conhecimento, escrever, seguidos por obter reconhecimento das realizações e ajudar pessoas, tanto na formação destas como na contribuição pelo conhecimento produzido pelos alunos. Destaca-se que apenas um dos entrevistados afirmou que, hoje, o objetivo principal é a qualidade de vida. Os principais objetivos mencionados pelos entrevistados - escrever 
e publicar - ressaltam uma das características fundamentais dessa profissão diretamente ligada à geração do conhecimento. As atividades de elaboração e de divulgação do conhecimento são fundamentais para o alcance do segundo objetivo mais destacado: o reconhecimento pelos pares, o que reforça sobremaneira a necessidade de capital simbólico nessa profissão.

Embora alguns aspectos referentes à luta pela acumulação de capital simbólico no campo científico tenham sido detectados na composição dos objetivos dos profissionais entrevistados, tais aspectos não se revelaram como plenamente determinantes. Aspectos de outra ordem, tais como autorrealização, continuar estudando e ajudar pessoas, também interferem no estabelecimento de objetivos. Esse importante contraponto à abordagem de Pierre Bourdieu nos afasta do determinismo estruturalista que marcou a obra desse autor. Por outro lado, mesmo relativizando o referido determinismo - o qual já foi amplamente comentado na literatura sociológica -, o emprego do conceito de campo científico elaborado por Bourdieu $(1976 ; 1994)$ nos permitiu empreender uma análise crítica e aprofundada do contexto dos pesquisadores entrevistados ${ }^{5}$. Ademais, relembramos que a análise aqui empreendida não é fundamentada unicamente na sociologia da ciência elaborada por esse autor, engajando, assim, estudos de vários outros autores.

Em relação ao cotidiano desses profissionais, percebeu-se que a agenda do professor-pesquisador engloba uma enorme diversidade de atividades, talvez o colocando no rol dos profissionais que lidam com maior pluralidade de atividades nos dias atuais. Tal pluralidade requer uma razoável versatilidade do profissional em seu cotidiano, indicando uma habilidade valorizada na contemporaneidade, mas isso também tem seu preço: o tempo destinado às atividades relativas à pesquisa (estudar, refletir, coletar e analisar dados, escrever, etc.) acaba sendo muito limitado, conduzindo o profissional a realizá-las quase sempre em finais de semana. As atividades mais gratificantes, justamente aquelas relacionadas à pesquisa, atividades da esfera criativa (BERRY, 1995) são, em geral, deslocadas para os finais de semana. Quanto a isso, os professores entrevistados acreditam que a instituição não dá o devido espaço para pesquisar. Destacam que pesquisar envolve uma série de atividades que a instituição não contempla no plano formal de trabalho. Por isso, o professor-pesquisador é obrigado a levar as principais tarefas da profissão para casa, para os horários de lazer, para manter um ritmo de produção científica exigido pelos órgãos que regulamentam o Ensino Superior na pós-graduação brasileira. Resgatamos, aqui, a crítica contundente feita por um dos entrevistados: "A rigor, a universidade não entendeu o papel de pesquisa do professor-pesquisador", isso porque sua agenda de trabalho semanal não possibilita integrar as atividades de pesquisa, principalmente as atividades referentes ao estudo e reflexão. Dessa maneira, as atividades do trabalho intelectual, das quais o profissional não se desliga ao sair do escritório, adentram ao final de semana, com leituras, elaboração e avaliação de artigos, por exemplo.

Berry (1995) constatou que, no caso francês, alguns pesquisadores chegam a dispensar as atividades de ensino em razão da elevada carga de trabalho e para se dedicar à pesquisa. Ressalta-se que, no contexto dos professores-pesquisadores entrevistados, isso não é possível, dado que o ensino é um dos elementos do tripé da universidade no Brasil e a profissão de pesquisador está vinculada à profissão de professor, notadamente na área de Administração. No entanto, não seria uma contradição a atividade de pesquisa (estudo, sistematização de dados, criação, publicação, etc.) representar apenas $24 \%$, em média, do tempo total de trabalho, tendo em vista que essa é a principal atividade relativa à realização dos objetivos profissionais desses atores e, também, a principal exigência dos órgãos reguladores? Não constituiria uma incompatibilidade, então, entre os objetivos e a agenda desse profissional?

Sob outra perspectiva, quais seriam os riscos de ser professor-pesquisador nesse contexto, com uma agenda que excede 50 horas de trabalho semanal? Não nos furtamos a trazer esses dados e questões enquanto frutos deste estudo exploratório para contribuir com o desenvolvimento do tema em trabalhos futuros. Alguns pesquisadores brasileiros já têm demonstrado forte preocupação com tal situação. A vida privada parece ter

5 Para uma análise aprofundada do determinismo da obra de Bourdieu, bem como das possibilidades de aproveitamento do potencial crítico dessa obra liberado de imperativos deterministas, ver Boltanski e Thévenot (2001) e, principalmente, Boltanski (2009). 
sido invadida e os limites entre o local de trabalho e o lar foram diluídos, principalmente com a flexibilização, a racionalidade mercantil e o uso das tecnologias: "Essa lógica produtivista transformou os intelectuais em estressados, medicados, eficientes operários de alto padrão, seres 'sem tempo' para a principal atribuição: analisar com rigor crítico a complexidade dos processos em curso (naturais ou sociais)" (MACHADO e BIANCHETTI, 2011, p. 251). Para Alcadipani (2011a), o que deveria ser a coroação de um trabalho sério de pesquisa e reflexão está se transformando; e, com a avaliação em triênios, transforma-se em um processo meramente quantitativo. Segundo Mattos (2008, p. 114), "à flor da pele está a pressão institucional por publicação".

Com este estudo, mesmo que exploratório, esperamos ter demonstrado a importância da sociologia da ciência para o aprofundamento da discussão sobre a profissão de professor-pesquisador em Administração em nosso país. Muito se fala informalmente dessa profissão, mas, apesar de termos uma centena de programas de pós-graduação nos quais formamos os futuros profissionais do campo, poucas são as discussões embasadas cientificamente sobre esse campo e seus atores. Portanto, acreditamos que há uma lacuna significativa na formação desses profissionais, ao passo que também cremos que a sociologia da ciência aplicada à Administração é um via para a minimização de tal lacuna.

Finalmente, como sugestão para trabalhos futuros, dando continuidade à investigação sobre o trabalho do professor-pesquisador, indicamos: i) estudos de natureza quantitativa que tenham como hipóteses as constatações desta pesquisa; ii) estudos que analisem as relações do campo a partir do conceito de campo científico elaborado por Bourdieu $(1976 ; 1994)$ complementado pela teoria de redes; e iii) estudos que aprofundem o exame das relações entre a vida pessoal e a vida profissional dos professores-pesquisadores.

\section{Referências}

ALCADIPANI, R. Academia e a fábrica de sardinhas. Organização \& Sociedade, v. 18, n. 57, p. 345-348, Abr./Jun. 2011a.

Resistir ao produtivismo: uma ode à perturbação Acadêmica. Cad. EBAPE.BR, v. 9, n. 4, p. 174-1178, 2011 b.

AUDET, M. Le procès des connaissances de l'administration. In: AUDET, M.; MALOUIN, J.-L. (Org.). La production des connaissances scientifiques de l'administration. Québec: Les Presses de l'Université Laval, 1986. 23-56 p.

BERRY, M. L'agenda du chercheur. L'action individuelle. Sciences humaines, n. 9, maio/jun. 1995.

BINI, T. J.; SERVA, M.; MELO, D. As habilidades de gestão dos coordenadores de grupos de pesquisa no campo da administração: uma análise baseada na sociologia da ciência. In: III COLÓQUIO INTERNACIONAL DE EPISTEMOLOGIA E SOCIOLOGIA DA CIÊNCIA DA ADMINISTRAÇÃO, 3., 2013, Florianópolis. Anais... • Florianópolis: Núcleo ORD-UFSC, 2013. 1-36 p.

BOLTANSKI, L. De la critique - précis de sociologie de l'émancipation. Paris: Gallimard, 2009.

; THÉVENOT, L. De la justification - les économies de la grandeur. Paris : Gallimard, 2001.

BOURDIEU, P. Le champ scientifique. Actes de La Recherche em Sciences Sociales, n. 2/3 , p. 88-104, Jun. 1976.

Homo Academicus. Paris: Éditions de Minuit, 1984.

. O campo científico. In: ORTIZ, R. (Org.). Pierre Bourdieu: sociologia. São Paulo: Ática, 1994.

Os usos sociais da ciência: por uma sociologia clínica do campo científico. São Paulo: Ed. Unesp, $2004 a$.

Para uma sociologia da ciência. Lisboa: Ed. 70, 2004b. 
CHARLE, C. Produireet diffuser: le arcanes de la reconnaissance. Sciences Humaines, n. 21, Jun./Jul. 1998.

DELPEUCH, J. L.; LAUVERGEON, A. Sur la trace des dirigeants (on the managers' trail). Gérer et comprendre, n. 2, Mar. 1986.

DORTIER, J.-F. Qu'est-ce qu'un chercheur? Sciences Humaines, n. 31, Dez. 2000/Jan. 2001.

FARIA, A. Repensando produtivismo em gestão no (e a partir do) Brasil. Cad. EBAPE.BR, v. 9, n. 4, p. 1164-1173, 2011.

FARIA, J. H.; BAIBICH-FARIA, T. M.; ZORZETTO FILHO, D. Discurso de Eros e prática de Thânatos: o esconderijo da dor e a síndrome do estoicismo hercúleo. In: ENCONTRO DA ASSOCIAÇÃO NACIONAL DE PÓSGRADUAÇÃO E PESQUISA EM ADMINISTRAÇÃO, 32., 2008, Rio de Janeiro. Anais... Rio de Janeiro: Anpad, 2008. 1-15 p.

FETZ, M.; DEFACCI, F. A.; NASCIMENTO, L. Olhares sociológicos sobre a ciência no século vinte: mudanças e continuidades. Sociologias, v. 13, n. 27, p. 284-317, 2011.

FREITAS, M. E. O pesquisador hoje: entre o artesanato intelectual e a produção em série. Cad. EBAPE.BR, v. 9, n. 4, p. 1158-1163, 2011.

LECLERC, G.; Qui sont les intellectuels? Le cas des universitaires. Sciences Humaines, v. 28, n. 157, Fev. 2005.

LOUVEL, S. Le monde des chercheurs. Sciences Humaines, v. 28, n. 157, fev. 2005.

MACHADO, A. M. N.; BIANCHETTI, L. (Des)fetichização do produtivismo acadêmico: desafios para o trabalhadorpesquisador. Revista de Administração de Empresas, v. 51, n. 3, p. 244-254, 2011.

MATOS, B. P. et al. Formação acadêmica e mercado de trabalho: os destinos profissionais de mestres e doutores em administração. In: VELLOSO, J. (Org.). Pós-graduação no Brasil: formação e trabalho de mestres e doutores no país. v. 1. Brasília, DF: Capes, 2002. 61-100 p.

MATTOS, P. L. C. L. Nós e os índices: a propósito da pressão institucional por publicação. Revista de Administração de Empresas, v. 48, n. 2, p. 144-149, Abr./Jun. 2008.

MERTON, R. K. The Sociology of Science: Theoretical and Empirical Investigations. Chicago: University of Chicago Press, 1973.

SERVA, M. A importação de metodologias administrativas no Brasil: uma análise semiológica. Revista Brasileira de Administração Pública, v. 26, n. 4, p. 128-144, 1992.

; PINHEIRO, D. M. Epistemologia e sociologia da ciência da administração: uma reflexão inicial sobre os estudos do campo no Brasil. In: ENCONTRO DA ASSOCIAÇÃO NACIONAL DE PÓS-GRADUAÇÃO E PESQUISA EM ADMINISTRAÇÃO, 33., 2009, São Paulo. Anais... São Paulo: Anpad, 2009. Disponível em: <http://www.anpad.org.br/diversos/trabalhos/EnANPAD/enanpad_2009/EPQ/2009_EPQ3113.pdf>. Acesso em: 6 abr. 2014.

TEIXEIRA, J. C. et al. Dinâmica de distribuição de fontes de capitais científicos entre docentes/pesquisadores de um programa de pós-graduação stricto-sensu de uma universidade pública. Avaliação, v. 17, n. 1, p. 179-206, 2012.

VELloSO, J. (Org.). Pós-graduação no Brasil: formação e trabalho de mestres e doutores no país. v. 1. Brasília, DF: Capes, 2002. 61-100 p.

WOOD JÚNIOR, T. O trabalho do cientista. Informativo Anpad, n. 6, Jan./Mar. 2005. Disponível em: <http://www.anpad.org.br/index_opiniao_opiniao.php?cod_informativo=6>. Acesso em: 1º mar. 2011. 